\title{
Size-resolved aerosol water uptake and cloud condensation nuclei measurements as measured above a Southeast Asian rainforest during OP3
}

\author{
M. Irwin ${ }^{1, *}$, N. Robinson ${ }^{1}$, J. D. Allan ${ }^{1,2}$, H. Coe ${ }^{1}$, and G. McFiggans ${ }^{1}$ \\ ${ }^{1}$ School of Earth, Atmospheric and Environmental Sciences, University of Manchester, Manchester, UK \\ ${ }^{2}$ National Centre for Atmospheric Science, University of Manchester, Manchester, UK \\ *now at: Department of Earth and Planetary Science, Graduate School of Science, University of Tokyo, Tokyo, Japan
}

Received: 18 December 2010 - Published in Atmos. Chem. Phys. Discuss.: 28 January 2011

Revised: 17 October 2011 - Accepted: 4 November 2011 - Published: 10 November 2011

\begin{abstract}
The influence of the properties of fine particles on the formation of clouds and precipitation in the tropical atmosphere is of primary importance to their impacts on radiative forcing and the hydrological cycle. Measurements of aerosol number size distribution, hygroscopicity in both sub- and supersaturated regimes and composition were taken between March and July 2008 in the tropical rainforest in Borneo, Malaysia, marking the first study of this type in an Asian tropical rainforest. Hygroscopic growth factors (GF) at $90 \%$ relative humidity $(\mathrm{RH})$ for the dry diameter range $D_{0}=32-258 \mathrm{~nm}$, supersaturated water uptake behaviour for the dry diameter range $D_{0}=45-300 \mathrm{~nm}$ and aerosol chemical composition were simultaneously measured using a Hygroscopicity Tandem Differential Mobility Analyser (HTDMA), a Droplet Measurement Technologies Cloud Condensation Nuclei counter $(\mathrm{CCNc})$ and an Aerodyne Aerosol Mass Spectrometer (AMS) respectively.

The hygroscopicity parameter $\kappa$ was derived from both $\mathrm{CCNc}$ and HTDMA measurements, with the resulting values of $\kappa$ ranging from $0.05-0.37$, and $0.17-0.37$, respectively. Although the total range of $\kappa$ values is in good agreement, there are inconsistencies between CCNc and HTDMA derived $\kappa$ values at different dry diameters. Results from a study with similar methodology performed in the Amazon rainforest report values for $\kappa$ within a similar range to those reported in this work, indicating that the aerosol as measured from both sites shows similar hygroscopic properties. However, the derived number of cloud condensation nuclei $\left(N_{\mathrm{CCN}}\right)$ were much higher in the present experiment than the
\end{abstract}

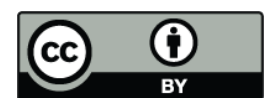

Correspondence to: G. McFiggans (g.mcfiggans@manchester.ac.uk)
Amazon, resulting in part from the increased total particle number concentrations observed in the Bornean rainforest. This contrast between the two environments may be of substantial importance in describing the impacts of particles in the tropical atmosphere.

\section{Introduction}

Of all the components of anthropogenic forcings, the complex interactions between atmospheric aerosols and cloud formation, properties and lifetime, collectively termed the "aerosol indirect effects" have been identified as having the greatest range of uncertainty (Forster et al., 2007). Cloud condensation nuclei (CCN) are the subset of the atmospheric aerosol which have the ability to nucleate cloud droplets in the presence of a water supersaturated air mass. The number of CCN may indirectly influence the radiative balance of the atmosphere by changing the number of cloud droplets, in turn changing the albedo, longevity and precipitation patterns of clouds (Twomey, 1977; Albrecht, 1989; Lohmann and Feichter, 2005 and Feichter et al., 2004; Andreae and Rosenfeld, 2008). A greater understanding of the $\mathrm{CCN}$ activation behaviour of the ambient aerosol distribution will improve predictions and further reduce this uncertainty.

The majority of land-based CCN studies report measurements from both moderately polluted continental regions and the marine environment, often in the mid-latitudes. The number of studies conducted in tropics is very low at present, with most limited to Amazonia, where Roberts et al. (2001, 2002, 2003); Andreae et al. (2004); Rissler et al. (2006); Vestin et al. (2007); Freud et al. (2008); Gunthe et al. (2009) classified the Amazonian aerosol as almost "marine"; with CCN

Published by Copernicus Publications on behalf of the European Geosciences Union. 
concentrations lower than would be expected for continental regimes. More recently, Chen et al. (2009) segregated periods of measurement from within the Amazon rainforest into in-Basin and out-of-Basin, where out-of-basin periods were characterised by aged organic material delivered by long range transport. Roberts et al. (2001) show that low $\mathrm{CCN}$ concentrations and high $\mathrm{CCN}$ to condensation nuclei $(\mathrm{CN})$ ratios over the unpolluted Amazon Basin resemble conditions previously reported from marine environments, though it is noted that similar $\mathrm{CCN}$ and $\mathrm{CN}$ concentrations prevail in both marine and continental regions in spite of the differences in aerosol composition.

Ambient aerosol particles contain a vast number of compounds, almost all in the organic fraction, many of which are unknown (Goldstein and Galbally, 2007; Hallquist et al., 2009). Natural volatile organic compounds (VOC) such as isoprene, monoterpenes and sesquiterpenes as well as anthropogenically-associated aromatic VOCs have been found to be precursors to secondary organic aerosol (SOA), which form when precursor species react with oxidants such as hydroxyl radicals, ozone and nitrogen oxides (Kanakidou et al., 2005). It has also been reported that in remote forested locations biogenic secondary organic aerosol (SOA) plays an important role in the growth of new particles (Allan et al., 2006; Laaksonen et al., 2008; Tunved et al., 2006). Claeys et al. (2004) and Henze and Seinfeld (2006) have shown the formation of secondary organic aerosol through photooxidation of isoprene in the ambient atmosphere, and Robinson et al. (2011) found evidence for isoprene SOA formation being important at this site. Isoprene is emitted in high quantities in rainforests and represents $38 \%$ of the Earth's Non-Methane Hydrocarbon (NMHC) budget (Hallquist et al., 2009). SOA could potentially change the CCN ability of particles through changes in overall bulk and/or surface composition and water affinity (Facchini et al., 2000; McFiggans et al., 2005, 2006).

Further to the aforementioned CCN studies, aerosol subsaturated water uptake has only been measured in the Amazonian regions of the tropics, where data from hygroscopicity tandem differential mobility analyser (HTDMA) experiments were used to predict aerosol CCN activity under supersaturated conditions (Zhou et al., 2002; Rissler et al., 2004, 2006; Vestin et al., 2007; Gunthe et al., 2009). Such reconciliation studies allow for comparisons with similar marine and continental reconciliation studies, probing our understanding of particle water uptake for a variety of different aerosol number-size distributions and compositions. Changes to a particle's physicochemical properties will change its propensity to behave as a CCN, which is discussed in detail by McFiggans et al. (2006). Organic molecules may influence both the Raoult and Kelvin terms of the Köhler equation by their effect on both water activity and surface tension respectively. VanReken et al. (2005) found a decreasing hygroscopicity in the supersaturated regime with aging time for SOA from biogenic precursors, whereas Duplissy et al. (2008) found an increasing hygroscopicity with aging time in both suband supersaturated regimes. Duplissy et al. (2008) went on to further demonstrate how, within error, the aerosol growth factor measurements and $\mathrm{CCN}$ activity of chamber-produced SOA can be reconciled with the use of the hygroscopicity parameter $\kappa$ from the semi-empirical $\kappa$-Köhler theory of Petters and Kreidenweis (2007), although Good et al. (2010c), using data from the same experiment, demonstrated that the ability to reconcile the measurements depended on the instrument used for the sub-saturated measurement. Previous reconciliation studies have found that when the aerosols were not strongly influenced by anthropogenic sources and contained low organic content, better agreements between the predicted and measured number of CCN $\left(N_{\mathrm{CCN}}\right)$ were observed (Liu et al., 1996; Chuang et al., 2000; Roberts et al., 2002; Snider et al., 2003; Broekhuizen et al., 2006; Rissler et al., 2006; Medina et al., 2007).

In order to better understand the role of particle size and composition on particle water uptake ability and thus the $\mathrm{CCN}$ potential, size-resolved ambient measurements are becoming increasingly common, though the relative importance of the aerosol number-size distribution and chemical composition is a topic of much debate (e.g., Wang et al., 2008; Good et al., 2010b; Dusek et al., 2010; Ervens et al., 2010; Juranyi et al., 2010; Rose et al., 2010, 2011; Wex et al., 2010). During the "Oxidant and particle photochemical processes above a South-East Asian tropical rainforest" (OP3) project (Hewitt et al., 2010), size-resolved aerosol water uptake in both the sub- $(\mathrm{RH}<100 \%)$ and supersaturated $(\mathrm{RH}>100 \%)$ regimes were measured for the first time in the Bornean rainforest. To link aerosol behaviour and air mass origin, we use a classification based on air mass history discussed by Robinson et al. (2011), who used this approach to show the influence of marine and terrestrial back trajectories using a method consistent with the in- and out-of-basin Amazonian study of Chen et al. (2009). The comparison of air mass origin to the study of aerosol water uptake behaviour as measured in this tropical rainforest is the first measurement of this type, allowing aerosol cloud forming potential in this region to be better quantified.

\section{Methodology}

\subsection{Measurement location and sampling}

The OP3 project was carried out during March through July 2008 at the Global Atmospheric Watch (GAW) station at Bukit Atur in the Danum Valley Conservation Area (location: $04^{\circ} 58^{\prime} 53^{\prime \prime} \mathrm{N}, 117^{\circ} 50^{\prime} 37^{\prime \prime} \mathrm{E}$, elevation $426 \mathrm{~m}$ a.m.s.l.). This study focuses on the measurement period OP3-III; 3 July through 20 July after setup and calibrations. For further information regarding the duration, location, meteorology, and weather of the project and for an overview of all measurements, please see Hewitt et al. (2010). 
Instrumentation was located inside an air-conditioned shipping container beneath the Global Atmospheric Watch (GAW) station, at the top of the Bukit Atur ridge in a small clearing above the forest canopy (with top of the canopy reaching $30 \mathrm{~m}$ up the $100 \mathrm{~m}$ tall GAW tower). Air was sampled from a common inlet system with an intake located at $30 \mathrm{~m}$ up the centre of the GAW tower. Air was drawn down a solar insulated $28 \mathrm{~m}, 15 \mathrm{~cm}$ diameter plastic inlet stack with a flow rate of 1500 litres per minute (LPM). At the bottom of this pipe, air was isokinetically subsampled from the centre of the flow at $351 \mathrm{~min}^{-1}$ and this air was then dried using a 780 tube nafion drier operating with a dry air counterflow. After the drier, the sample air was decelerated to obtain laminar flow conditions and distributed to instrumentation in the container using an isokinetic sub-sampling system.

\subsection{CCN Measurements}

CCN concentrations as a function of dry diameter $\left(D_{0}\right.$, $\mathrm{RH}<20 \%$ ) and supersaturation were measured using the continuous flow thermal-gradient Cloud Condensation $\mathrm{Nu}$ clei counter (DMT-CCN counter, Roberts and Nenes, 2005) and were used to derive particle critical supersaturation, $S_{\mathrm{c}, \mathrm{D} 0}$, and threshold dry diameter for activation, $D_{50, \mathrm{~S}}$. The $\mathrm{CCN}$ counter was operated in parallel to a condensation nucleus (CN) counter (TSI-3010) downstream of a scanning mobility particle sizer (SMPS, TSI-3080, DMA column 3081). The TSI 3080 SMPS was operated as a differential mobility particle sizer (DMPS), stepping discretely through dry diameters from $20 \mathrm{~nm}$ to $300 \mathrm{~nm}$. This allowed simultaneous measurement of $\mathrm{CCN}$ and $\mathrm{CN}$ number-size distributions whilst avoiding smearing of sizes whilst scanning the voltage on the SMPS central rod. A settling time of $180 \mathrm{~s}$ before sizing allowed the stabilisation of temperatures within the CCN counter, with the DMA voltage held constant for periods of $12 \mathrm{~s}$ to increase data yield. The $\mathrm{CCN}$ counter was stepped through five different column temperature gradients $(\Delta T)$ of $2.56,3.62,6.52,8.24$ and $12.2{ }^{\circ} \mathrm{C}$, calibrated to $0.11 \%, 0.18 \%, 0.37 \%, 0.48 \%$ and $0.73 \%$ as described below, repeatedly at 10 minute intervals. The first set point of each S-step was duplicated at the beginning of the scan to allow temperatures within the column to stabilise further, giving a $1 \mathrm{hr}$ time resolution for this measurement. The CCN and $\mathrm{CN}$ number-size distributions were corrected for multiple charge events using the probability coefficients specified by Wiedensohler (1987). Both the CCNc and CN counter were operated with a sample flow of $0.49 \pm 0.01$ LPM (litre per minute), with the DMA operated at a sheath to aerosol ratio of 10:1.

The CCN counter was calibrated using nebulised monodisperse sodium chloride and ammonium sulphate ( $>$ 99.95\% Sigma Aldrich) aerosol. The shape of the chargeneutralized size distribution from the nebuliser is such that multiple charging probabilities are extremely low, and as consequence no charge correction was needed. The calibra- tion aerosol was nebulised, dried, size selected using a DMA and split between the $\mathrm{CCN}$ counter and $\mathrm{CN}$ counter. In total, 20 dry diameters were stepped through between $20 \mathrm{~nm}$ and $220 \mathrm{~nm}$, though complications due to software malfunction increased the lower limit to $45 \mathrm{~nm}$. The fraction of aerosol activated at a given supersaturation and dry diameter, $F_{\mathrm{A}}\left(\mathrm{S}, \mathrm{D}_{0}\right)$, was measured as a function of the temperature gradient down the column at selected dry diameters. Assuming the system to have a symmetrical transfer function, the data were fitted with an error-weighted sigmoidal function and the temperature gradient at which $F_{\mathrm{A}}\left(\mathrm{S}, \mathrm{D}_{0}\right)=50 \%$ was determined, and interpreted as the critical supersaturation if plotted against supersaturation setpoints $\left(S_{\text {set }}\right)$ or as the threshold dry diameter for activation, $D_{50, \mathrm{~S}}$, if plotted against $D_{0}$ (hereafter referred to as S-step and D-step analysis respectively, explained in Sect. 1 of the Supplement). The supersaturation was then calibrated to agree with the theoretical critical supersaturation calculated using ADDEM (Topping et al., 2005). The CCN counter was operated with an inlet temperature of $\sim 20^{\circ} \mathrm{C}$ for the duration of the experiment. This methodology of measurement is consistent with those described by Good et al. (2010a) and Irwin et al. (2010), and is summarised in the Supplement.

\subsection{Hygroscopic growth factor measurements}

Hygroscopic growth factor probability distributions, $p(\mathrm{GF})$, were measured as a function of six dry $(\mathrm{RH}<20 \%)$ diameters $\left(D_{0}=32 \mathrm{~nm}, 53 \mathrm{~nm}, 104 \mathrm{~nm}, 155 \mathrm{~nm}, 207 \mathrm{~nm}\right.$ and $258 \mathrm{~nm}$ ) at $90 \%$ relative humidity $(\mathrm{RH})$ by a hygroscopicity tandem differential mobility analyser (HTDMA) with $1 \mathrm{~h}$ time resolution. The HTDMA was operated with a sample aerosol flow rate of $0.5 \pm 0.05$ LPM. A dry aerosol mobility is selected by the first DMA which is then humidified to $90 \% \mathrm{RH}$ and sized again using a second DMA, which steps through voltages, giving a size distribution of the humidified aerosol. The growth factor is defined as the particle diameter at a given RH, $D$, divided by its dry diameter, $D_{0}$. The HTDMA used in this study was the modified version shown by Good et al. (2010a), which was principally described by Cubison et al. (2005). Following quality assurance, the HTDMA data was inverted using the multi-triangle inversion described by Gysel et al. (2009), resulting in the growth factor probability distribution, $p(\mathrm{GF})$. Instrumental errors (e.g. precision of RH measurement) were propagated through to derived data products (such as the single hygroscopicity parameter $\kappa$ ) as described in the Supplement.

\subsection{Measurements of aerosol composition}

Non-refractory aerosol particle composition was measured by a High-Resolution Time-of-Flight Aerosol Mass Spectrometer (HR-ToF-AMS, Aerodyne Research Inc,; DeCarlo et al., 2006; Canagaratna et al., 2007). The instrument was operated with a heater temperature of approximately $550^{\circ} \mathrm{C}$ 
and is capable of measuring particles from $40 \mathrm{~nm}-700 \mathrm{~nm}$ vacuum aerodynamic diameter (Jayne et al., 2000; Liu et al., 1995a,b). The mass size distribution of the aerosol particles was monitored by measuring the mass as a function of flight time of the sampled particles in vacuum. Standard data analysis techniques were applied (Allan et al., 2003). The collection efficiency used for the OP3 data was 0.5 , which is consistent with results from the laboratory (Matthew et al., 2008) and results in good agreement with the integrated submicron volume time series from collocated DMPS data Robinson et al. (2011), assuming sphericity and the densities measured by Cross et al. (2007).

Aerosol number-size distributions between $20 \mathrm{~nm}$ and $700 \mathrm{~nm}$ were measured by a differential mobility particle analyzer (DMPS; Williams et al., 2007). A complete mobility scan was performed every $10 \mathrm{~min}$. Aerosol optical absorption was measured with a Thermo Scientific model 5012 Multi Angle Absorption Photometer (MAAP; Petzold and Schönlinner, 2004) which reports in black carbon equivalent loading.

\subsection{Air mass classification}

Data from the final OP3 campaign, OP3-III which spanned 23 June-23 July, are presented as this period had the most complete data coverage (for a list of the campaigns see Hewitt et al., 2010).

A backwards air mass trajectory analysis was performed for the OP3 campaign, and is detailed by Robinson et al. (2011). In this case, back trajectories were calculated from ECMWF wind fields (BADC, 2009). One trajectory per hour was generated for the whole of the OP3 project, with any trajectories that impacted with the ground discarded. All analysis in this paper is segregated using the back trajectory analysis performed with $950 \mathrm{hPa}$ data. OP3 has been segregated into five distinct periods of influence defined by different air mass (Fig. S1 in the Supplement), defined by back-trajectory cluster analysis and as such the nomenclature is a qualitative guide, rather than assuring the certainty of air mass origin.

During OP3-III, 4 of the 5 air mass sectors were observed; with the Marine and Terrestrial periods dominating the sectorisation (Fig. 1a). The four day Terrestrial period is characterised by a relatively high organic:sulphate ratio (Fig. 1b) when compared to the rest of OP3-III. In contrast, the observed organic:sulphate ratio is much lower during the Marine period $(<2: 1)$. No hygroscopicity data were collected during air masses designated to be of "coastal" origin during OP3-III, and only around $24 \mathrm{~h}$ worth of data were attributed to the Westerly and Northeasterly back trajectories respectively (Fig. 1a).

\section{Results}

\subsection{Aerosol composition and size distributions}

The measurements were carried out during Borneo's dry season (the Sabah region has a dry season from April to October), though year-round rainfall varies only slightly. The number-size distribution for the campaign was characterised by a broad monomodal Aitken mode peak between $40 \mathrm{~nm}$ and $70 \mathrm{~nm}$, with occasional high particle concentrations below this diameter (Fig. 1c). Whitehead et al. (2010) present an overview of the aerosol dynamics and size distributions in an Optical Particle Counter (OPC) study representing the accumulation mode. Briefly, from the above canopy measurements it was found that the coarse mode aerosol did not contribute to the number-size distribution, as the number concentrations were extremely low above diameters of $300 \mathrm{~nm}$. Particle number concentrations were typically higher across the submicron size distribution overnight (18:00-06:00 LT, as shown in Fig 1d). Additionally, total particle number concentrations above $0.01 \mu \mathrm{m}$, as measured by a TSI $3010 \mathrm{CPC}$ at the top of the GAW tower, were also highest overnight, as shown in Fig. 3 by (Whitehead et al., 2010).

The high organic:sulphate ratio seen during 4 to 5 July of the Terrestrial period (Fig. 1b), is characterised by relatively low number concentrations at all sizes. From the latter half of 5 July through 7 July, the organic:sulphate ratio is seen to decrease and the particle number concentration between $20 \mathrm{~nm}$ and $100 \mathrm{~nm}$ increase, after which the period is attributed to the Unclassified sector, before switching to Marine. The $\mathrm{BC}$ equivalent loading as measured by the MAAP shows BC levels to be relatively low in contrast to the increased organic loading reported by the HR-AMS for this period. The Marine period has a relatively low and stable organic:sulphate ratio ranging from $0.25-2$, though the particle concentration is seen to vary quite dramatically across the number-size distribution. Most notably, the first half of the Marine period ( 8 July through 12 July) is characterised by an overall low particle concentration above $70 \mathrm{~nm}$, with a peak in the number-size distribution around $40 \mathrm{~nm} .10$ July is characterised by a higher than average organic:sulphate ratio, which peaks at midday, followed by very high particle concentrations $<40 \mathrm{~nm}$. The latter half of 12 July is characterised by very high particle concentrations between $20 \mathrm{~nm}$ and $110 \mathrm{~nm}$. Similar behaviour is exhibited on the evening of 12 July and less so on the afternoon of 13 July, though for a much shorter period of time in each case. 14 July is shown to have much lower particle concentrations across the size range. The Marine period from midday on 17 July through 19 July is characterised by a slightly higher organic:sulphate ratio than the earlier Marine period (from 0.44-2.2), an increase in $\mathrm{BC}$ loading, and number concentrations are much higher at sizes $>40 \mathrm{~nm}$.

Figure $1 \mathrm{~d}$ shows the substantial diurnal variability in particle concentrations as a function of size. Typically, higher 
a)

b)
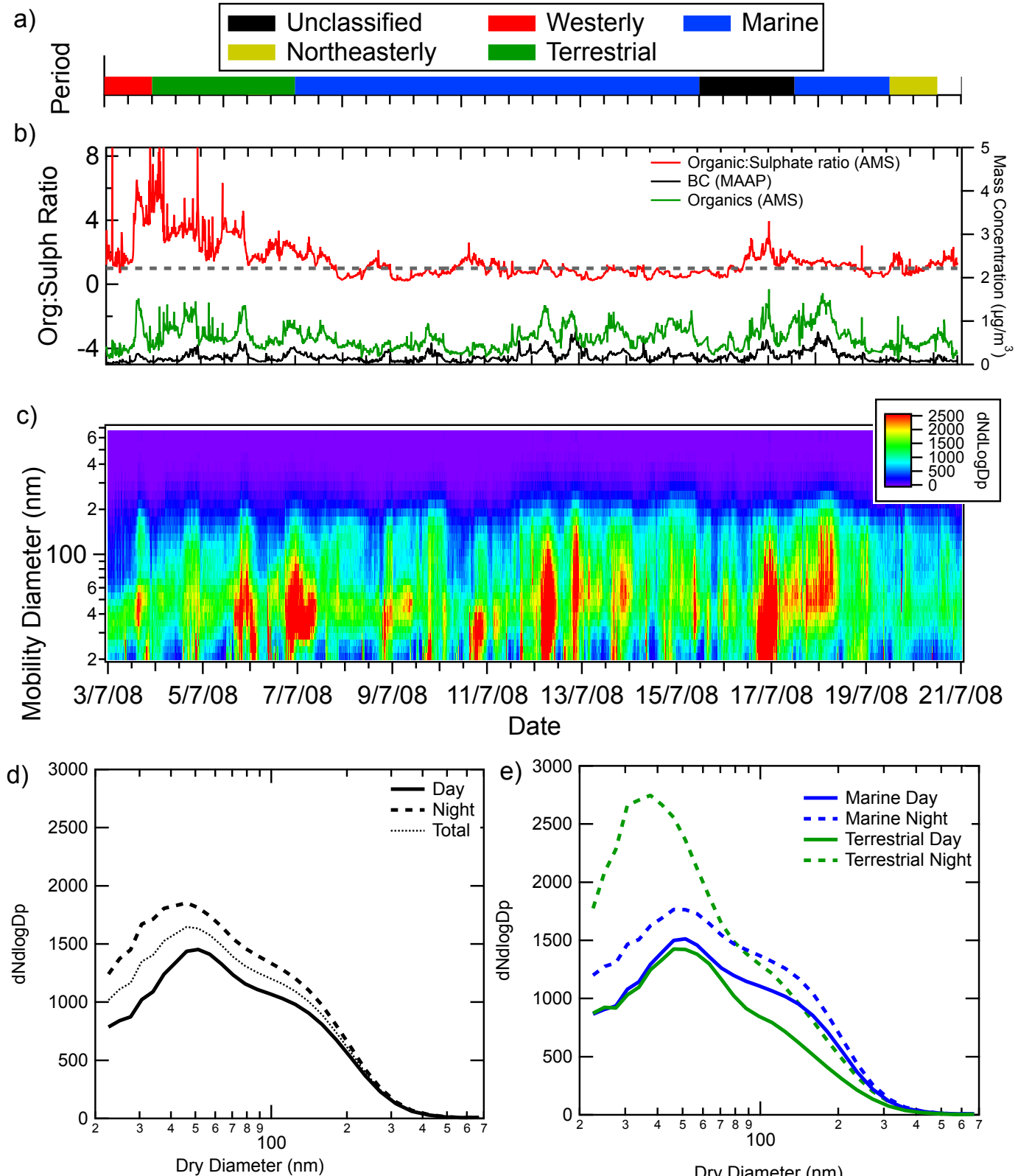

Dry Diameter (nm)

Fig. 1. (a) the sectorisation of the OP3-III campaign, for the time series of the aerosol instrumentation used in this paper. (b) the total organic:sulphate ratio, constituent organic mass as measured by the HR-AMS and BC as measured by MAAP. (c) the DMPS number-size distribution for the measurement period. The periods are defined as 0 Unclassified, 1 Westerly, 2 Coastal, 3 Marine, 4 Northeasterly and 5 Terrestrial. (d) Day and Night averages and (e) Sectorised averages of the DMPS data.

particle number between $25 \mathrm{~nm}$ and $200 \mathrm{~nm}$ was observed during the night throughout the campaign. Figure 1e shows a marked difference in the average size distribution between day and night for the marine and terrestrial periods, with the night time terrestrial number-size distribution exhibiting a departure from the overall trend with a much higher particle number concentration below $70 \mathrm{~nm}$.

Figure 2 shows the Fraction Activated, $F_{\mathrm{A}}\left(\mathrm{S}, \mathrm{D}_{0}\right)$, of aerosol at each CCNc calibrated supersaturation setting, $S_{\text {set }}$, as a function of particle dry diameter, $D_{0}$. The open circles represent the average $F_{\mathrm{A}}\left(\mathrm{S}, \mathrm{D}_{0}\right)$ during the day (06:0018:00 LT) and the solid circles the night-time average showing no significant difference in activation behaviour; the solid line represents the average $F_{\mathrm{A}}\left(\mathrm{S}, \mathrm{D}_{0}\right)$ for the entire measurement period at each supersaturation, with the error bars showing the standard deviation. There is an apparent departure from the monotonic trend in the fraction activated for the three highest supersaturations with particles 

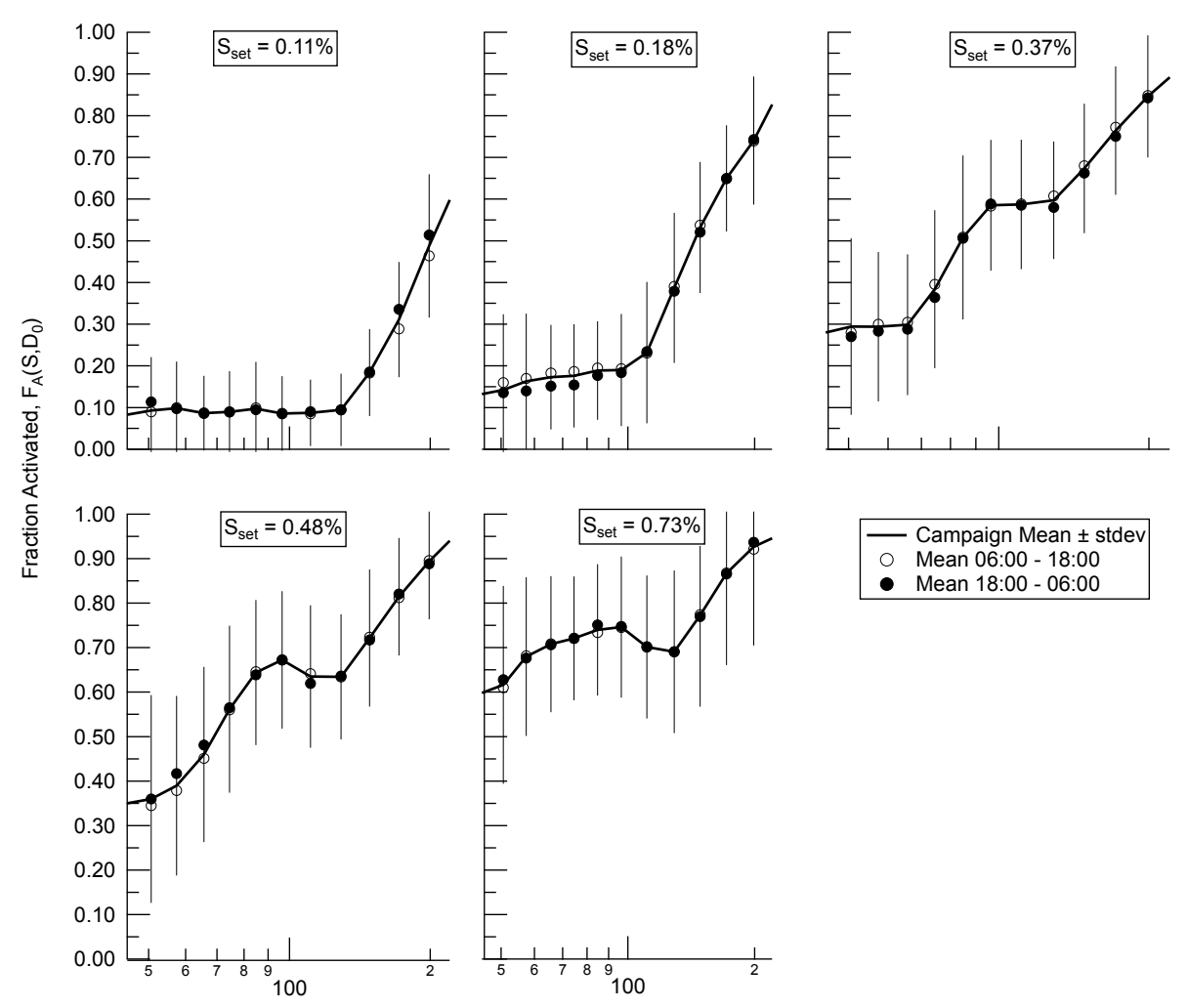

Fig. 2. The aerosol fraction activated $F_{\mathrm{A}}\left(\mathrm{S}, \mathrm{D}_{0}\right)$ against dry diameter, for each $S_{\text {set }}$ used in OP3-III. The campaign mean is shown as a solid black line, with error bars illustrating the standard deviation. The data was segregated into day and night, denoted by hollow and solid circles respectively.

below $100 \mathrm{~nm}$ appearing to activate more readily than those just above $100 \mathrm{~nm}$. Owing to low mass loadings, there are no size-resolved composition data from the AMS available, though the aerosol growth factor and mixing state (shown by HTDMA measurements) will allow for an interpretation of aerosol composition at each size (see Sect. 3.4 for the results of HTDMA measurements).

\subsection{Activable fraction of particles}

The particle activation data were further split into the Terrestrial and Marine periods; the temporal resolution of the other periods was too low to sectorise effectively. As for the entire dataset, day and night activation behaviour for both Marine and Terrestrial did not differ significantly. As the HTDMA and CCNc data cannot be compared on a diameterfor-diameter basis, the $\mathrm{CCNc}$ data were binned into 5 discrete bins (with [D0.D1] and [D1.D2] for the lower and upper bins respectively). In order to probe the effects of aerosol particle composition on hygroscopicity, the data was screened for external mixing (which we attributed to data where the mean growth factor deviated by more than $5 \%$ from the peak growth factor bin). Figure 3 shows the fraction of aerosol activated as a function of particle dry diameter. The grey dashed lines indicate the average $F_{\mathrm{A}}\left(\mathrm{S}, \mathrm{D}_{0}\right)$ of the Marine and Terrestrial clusters, with the coloured lines indicating the $F_{\mathrm{A}}\left(\mathrm{S}, \mathrm{D}_{0}\right)$ during periods where the mean growth factor was within $5 \%$ deviation of the peak growth factor, for each $S_{\text {set }}$. Both clusters exhibit similar trends; particle activation increasing with an increase in supersaturation. Though the external mixture screened data shows some small differences to each sector's mean $F_{\mathrm{A}}\left(\mathrm{S}, \mathrm{D}_{0}\right)$, as Fig. 2 has shown, this is well within measurement variability. The previously noted departure from monotonic trend across the size range is consistent in each case; at supersaturations above $0.37 \%\left(S_{\mathrm{set} 2}\right)$, which has the smallest overall standard error, see Fig. S2 in the Supplement, particles of 80 to $90 \mathrm{~nm}$ diameter activate more readily than particles of 100 to $120 \mathrm{~nm}$ in both clusters, indicating more soluble material at the smaller sizes, with the deviation from monotonic behaviour more pronounced in the marine cluster. Overall, particles from the Terrestrial sector activate less readily than those from the Marine sector. 


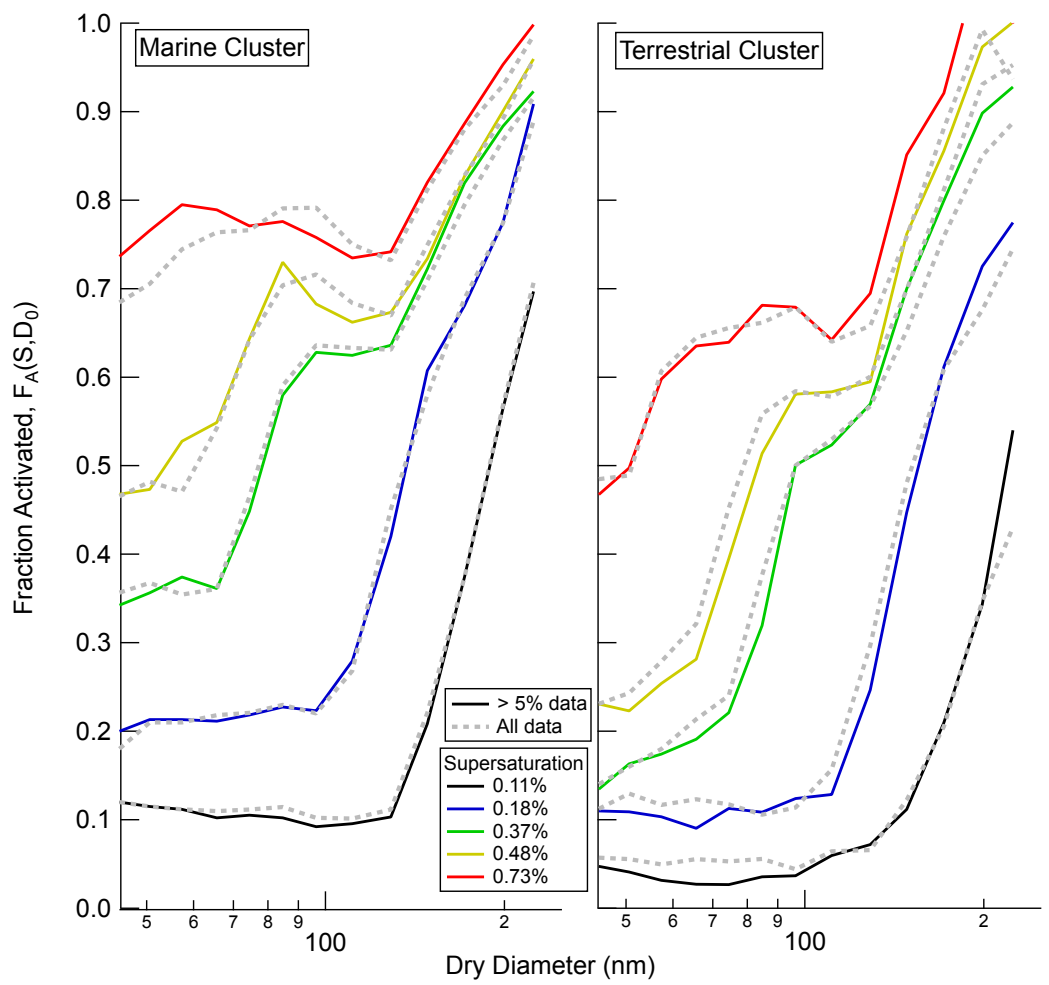

Fig. 3. The fraction activated at each supersaturation as a function of dry diameter, split for the sectorisations Marine and Terrestrial. The grey lines indicate the campaign mean data, and the coloured lines show data from when the HTDMA mean corrected growth factor had smaller than $5 \%$ deviation from the peak growth factor bin.

\subsection{Particle critical supersaturation}

The particle critical supersaturation (the supersaturation above which a particle of dry diameter $D_{0}$ will experience runaway growth into a cloud droplet, denoted $S_{\mathrm{c}, \mathrm{D} 0}$ ) has been derived for the ambient dry particle size range $65 \mathrm{~nm}<$ $D_{0}<210 \mathrm{~nm}$. Data outside this range were dominated by large uncertainty, since particles with critical supersaturation close to the CCNc maximum and minimum $S_{\text {set }}$ will be constraining the sigmoidal fit with few data on one side or the other of $F_{\mathrm{A}}\left(\mathrm{S}, \mathrm{D}_{0}\right)=50 \%$, increasing the uncertainty of the fit. Such data are removed during the quality assurance process. This does not substantially limit the data analysis since it is the size range that will almost certainly span the threshold dry diameter for droplet activation at reasonable atmospheric updraught speeds and ambient supersaturations (e.g. $S_{\max }<\approx 0.2 \%$ for a more hygroscopic aerosol, where the Amazonian study of Reutter et al. (2009) found the variability of initial cloud droplet number concentration in convective clouds to be mostly dominated by the variability of updraft velocity and aerosol particle number concentration in the accumulation mode).

The Terrestrial cluster has a slightly higher activated fraction at the highest supersaturation $(0.73 \%)$ between 80 to $90 \mathrm{~nm}$ than at the larger dry diameters of 100 to $120 \mathrm{~nm}$ as shown in Fig. 3. However, as the activated fraction increases at lower supersaturations for the same diameters the derived critical supersaturation will increase, though the error associated with the sigmoid fit will be larger. Similarly for the Marine sector, $F_{\mathrm{A}}\left(\mathrm{S}, \mathrm{D}_{0}\right)$ data at $0.48 \%$ and $0.73 \%$ both decrease between 80 to $110 \mathrm{~nm}$ which have a greater influence over the sigmoidal function and do in fact decrease the critical supersaturation. The critical supersaturation data are presented in Table 1 for both sectors for the measured size distribution.

Figure 4 shows how the peaks in the organic:sulphate ratio (see Fig. 1) are tracked well by the particle critical supersaturation, and the reduced relative organic content seen during the Marine period is characterised by a reduction in the critical supersaturation (this may be expected if the particles can indeed be attributed to be of marine origin with higher relative sulphate or sea salt content).

The $S_{\mathrm{c}, \mathrm{D} 0}$ data was sectorised for Marine and Terrestrial back trajectories, the results of which are shown in Table 1 . There is less variability in $S_{\mathrm{c}, \mathrm{D} 0}$ during the Terrestrial period (denoted by $\sigma$ ), and there is an overall higher organic:sulphate ratio during this period (Figs. 1 and 4). The particles attributed to the Marine sector are easier to activate, requiring a lower supersaturation at all sizes until almost all particles are activated over $D_{0}=200 \mathrm{~nm}$, though this similarity may partially be attributed to instrument limitations, as the lowest supersaturation setting was $0.11 \%$, and 


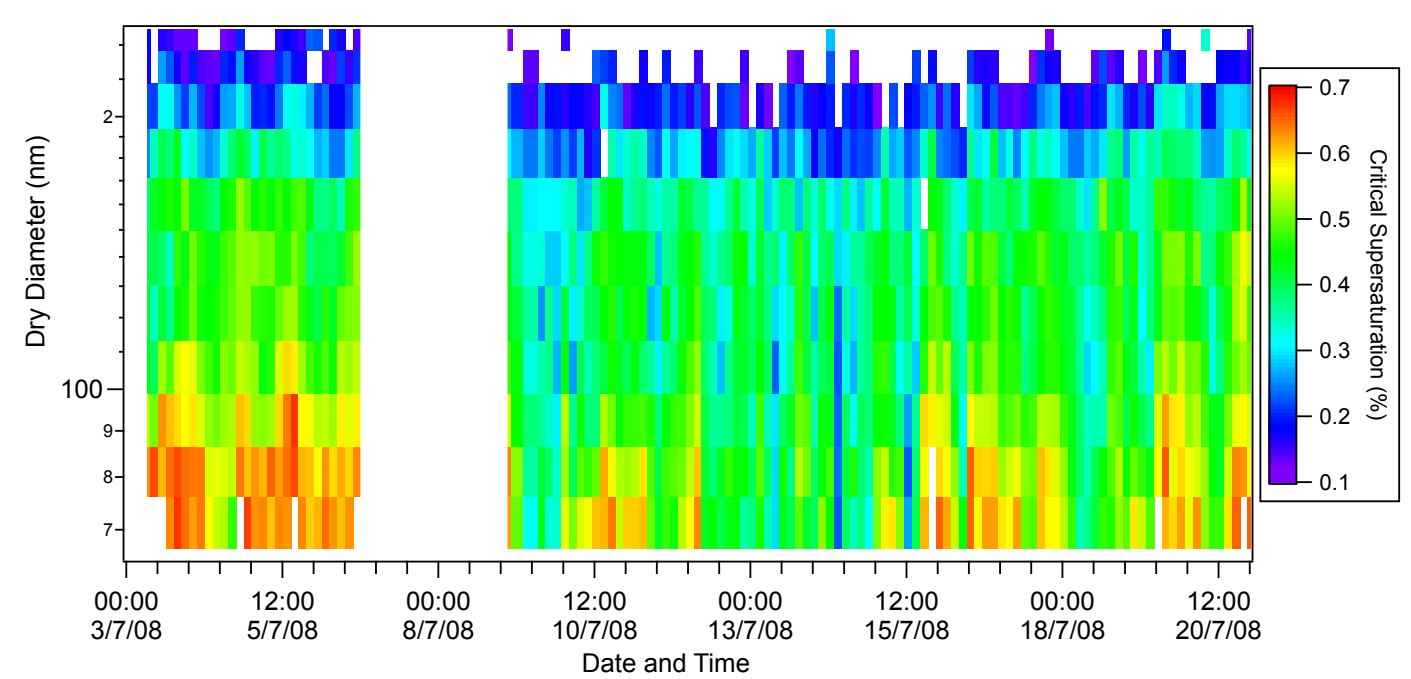

Fig. 4. The derived critical supersaturation for OP3-III as a function of dry diameter.

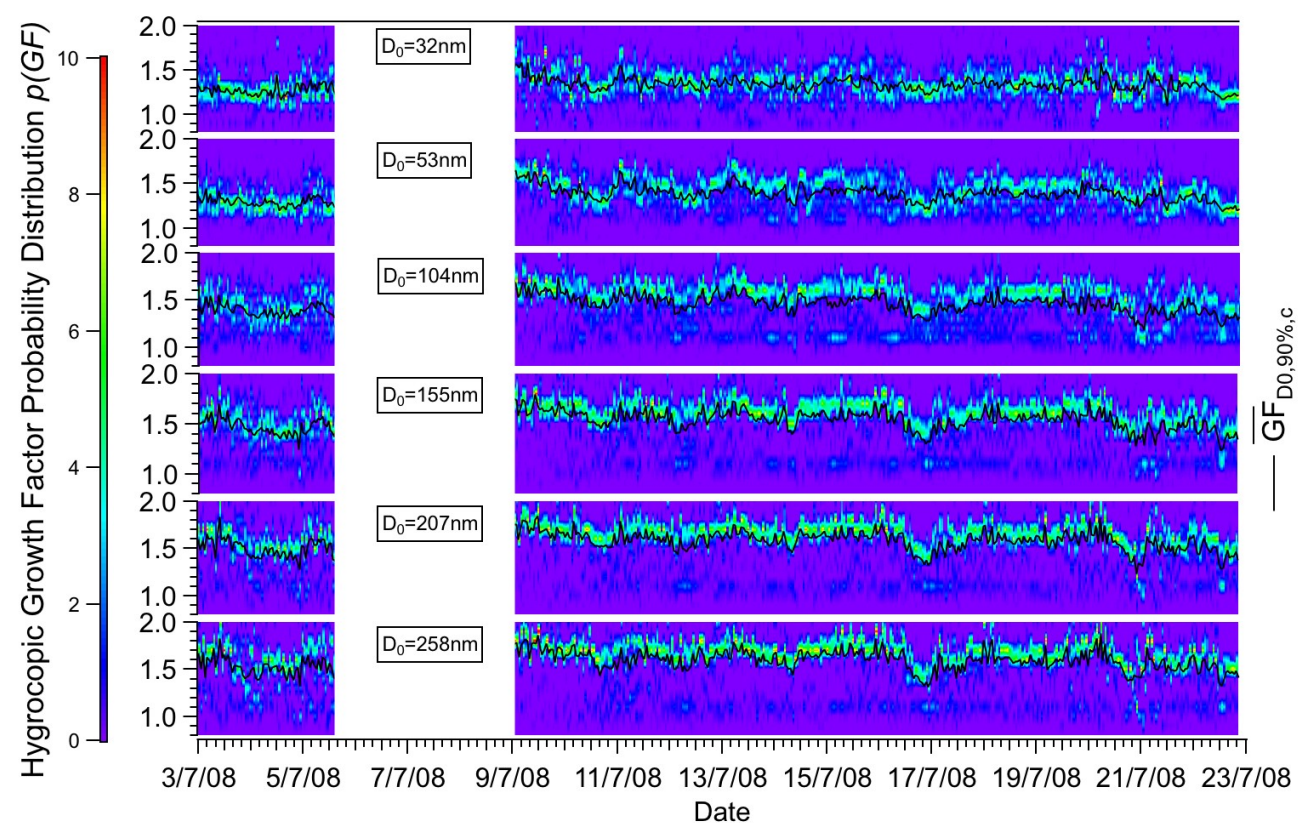

Fig. 5. The HTDMA growth factor probability distribution, $p(\mathrm{GF})$, and RH-corrected mean growth factor, $\overline{\mathrm{GF}}_{\mathrm{D} 0,90 \%, \mathrm{c}}$ at $90 \%$, for 6 dry diameters as measured by the HTDMA.

so only critical supersaturations above this value may be derived (see Fig. S2 in the Supplement).

\subsection{Aerosol sub-saturated water uptake}

Aerosol water uptake at $90 \%$ relative humidity, $\mathrm{RH}$, was measured using an HTDMA. The instrument ran well for the majority of OP3-III, with little deviation from the target RH. The growth factor probability distribution, $p(\mathrm{GF})$, is highly variable (Fig. 5), with the same trends being followed at all sizes. Compared to other projects using the same measure- ment (such as that shown by Irwin et al., 2010), the growth factor probability distribution for a single scan is typically quite broad; clearly indicating a range of compositions at any given size, exhibiting a broad continuum of growth factors rather than falling into multiple externally mixed classes. The extent of this external mixing becomes increasingly distinct when the less hygroscopic mode with a growth factor of $\sim 1.1$ separates from the more hygroscopic mode particles with their higher growth factors typically increasing with increasing dry diameter (Fig. 5 and average $p(\mathrm{GF})$ shown in Fig. S4 in the Supplement). The more hygroscopic mode 


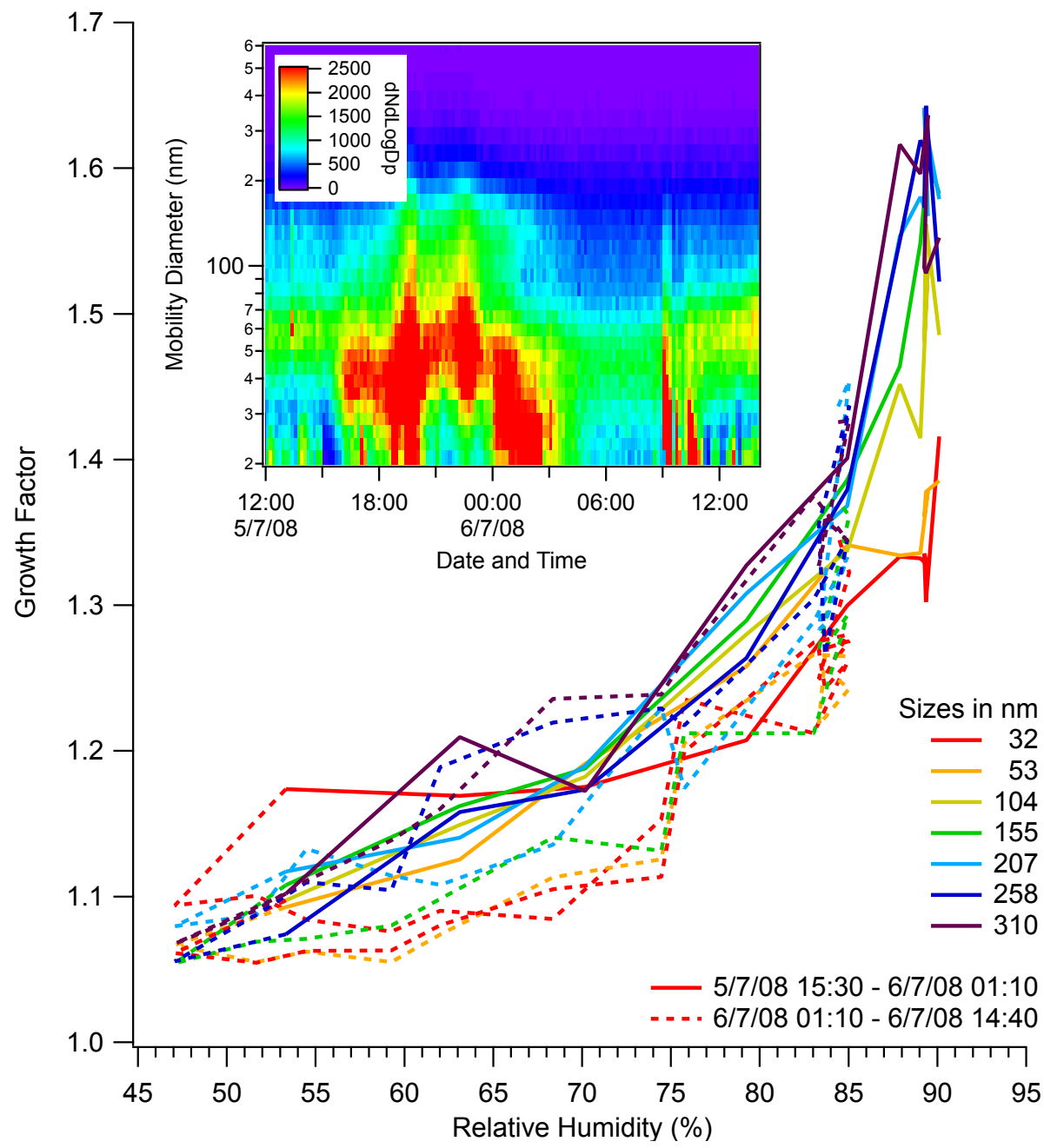

Fig. 6. A humidogram taking during a Terrestrial sector during OP3-III. The solid and dashed lines indicate the evening and morning measurement; roughly corresponding to the measurement of the efflorescence and deliquescence branches respectively. Note: data $\mathrm{RH}<45 \%$ were unavailable.

Table 1. A table of mean critical supersaturation, $S_{\mathrm{c}, \mathrm{D} 0}$, for each measured dry diameter, $D_{0}$, for the Marine and Terrestrial periods of OP3-III, with standard deviation, $\sigma$.

\begin{tabular}{lcccc}
\hline & Marine & \multicolumn{3}{c}{ Terrestrial } \\
$D_{0}$ & $S_{\mathrm{c}, \mathrm{D} 0}(\%)$ & $\sigma$ & $S_{\mathrm{c}, \mathrm{D} 0}(\%)$ & $\sigma$ \\
\hline $65 \mathrm{~nm}$ & 0.482 & 0.086 & 0.630 & 0.037 \\
$74 \mathrm{~nm}$ & 0.428 & 0.079 & 0.560 & 0.044 \\
$84 \mathrm{~nm}$ & 0.391 & 0.070 & 0.512 & 0.041 \\
$96 \mathrm{~nm}$ & 0.388 & 0.060 & 0.477 & 0.030 \\
$110 \mathrm{~nm}$ & 0.394 & 0.058 & 0.465 & 0.042 \\
$129 \mathrm{~nm}$ & 0.361 & 0.052 & 0.431 & 0.060 \\
$148 \mathrm{~nm}$ & 0.209 & 0.058 & 0.257 & 0.054 \\
$171 \mathrm{~nm}$ & 0.202 & 0.047 & 0.246 & 0.054 \\
$199 \mathrm{~nm}$ & 0.182 & 0.051 & 0.184 & 0.052 \\
$224 \mathrm{~nm}$ & 0.183 & 0.074 & 0.182 & 0.053 \\
\hline
\end{tabular}

shown at the larger diameters appears to be an internal mixture, with a narrow distribution of growth factor values. The departure from monotonic trend for particles of dry diameters $32 \mathrm{~nm}$ and $53 \mathrm{~nm}$ (shown in Fig. 3) cannot be solely attributed to external mixing, as the variation in the activated fraction data is greater than the difference in this variation between internally mixed and externally mixed data.

An aerosol humidogram was performed between 5 and 6 July (Fig. 6); a terrestrial period with higher variability in the DMPS number-size distribution for the duration of the humidogram (see Fig. 6 inset). It should be noted that no measurements were possible below $45 \% \mathrm{RH}$. The majority of the data from the humidogram corresponds to the morning and early afternoon of 6 July, which is characterised by low particle concentrations above $60 \mathrm{~nm}$, but high concentrations between $20 \mathrm{~nm}$ and $60 \mathrm{~nm}$ in the late morning. The humidogram was started at $90 \% \mathrm{RH}$ and brought down to 
$45 \% \mathrm{RH}$, whence the $\mathrm{RH}$ was increased again up to $85 \%$. Contrasting the efflorescence and deliquescence branches of the humidogram (denoted by solid and dashed lines respectively), reveals the late-afternoon/evening aerosol particles below $258 \mathrm{~nm}$ to be more hygroscopic at the same RH, than particles of the same dry diameter the following morning. This could be due to the increasing ambient RH as the boundary layer (and moisture) lifts up the side of the valley, scavenging the most hygroscopic particles. The lack of a welldefined deliquescence point is consistent with aerosol comprising multiple components able to attract liquid water to the particles below the deliquescence point of commonly expected inorganic salts (Marcolli et al., 2004). The two smallest sizes $(32 \mathrm{~nm}$ and $53 \mathrm{~nm})$ do not achieve the same high growth factor of 1.4-1.5 seen by the larger particles; consistent with activation data (Figs. 2 and 3).

\subsection{Hygroscopicity}

Fig. S5a in the Supplement shows the average of the RHcorrected mean growth factor at $90 \% \mathrm{RH}$ for the Terrestrial sector plotted against that of the Marine sector, coloured as a function of particle dry diameter. The Marine sector shows an overall higher growth factor at each size than for the Terrestrial sector, with particles of $D_{0}=32 \mathrm{~nm}$ showing the closest overall agreement in growth factor between the two sectors.

Consistent with these data, Fig. S5b in the Supplement shows that the Terrestrial sector requires a consistently higher supersaturation to activate the particles compared to that of the Marine sector, which more readily activates at each dry diameter. The critical supersaturation is most variable for the smallest dry diameters, where a higher variability in the mean hygroscopic growth factor could have introduced higher variability in the activated fraction and subsequently critical supersaturation, as at these dry diameters, the aerosol is mostly internally mixed (or comprises external mixtures of a narrow hygroscopic range). Figure $\mathrm{S} 5 \mathrm{~b}$ in fact shows the same information as Fig. 3, as $S_{\mathrm{c}, D_{0}}$ is derived from $F_{\mathrm{A}}\left(\mathrm{S}, \mathrm{D}_{0}\right)$. The larger sizes show overall agreement for both sectors, which was previously shown in Table 1 .

\subsection{Reconciling sub- and supersaturated hygroscopicity}

An aerosol particle's ability to behave as a CCN is dependent on both particle size and composition. The composition of a solution determines its water activity $\left(a_{\mathrm{w}}\right)$ and surface tension $(\sigma)$ for a given water content. The relationship between a droplet's size and saturation ratio $(S)$ can be described using these parameters in the Köhler equation (Eq. 1) (Köhler, 1936; McFiggans et al., 2006),

$S=a_{\mathrm{w}} \exp K_{\mathrm{e}}$

where $K_{\mathrm{e}}$ is the Kelvin or surface tension term.

The $\kappa$-Köhler model of Petters and Kreidenweis (2007), defines a single hygroscopicity parameter $\kappa$ to describe the

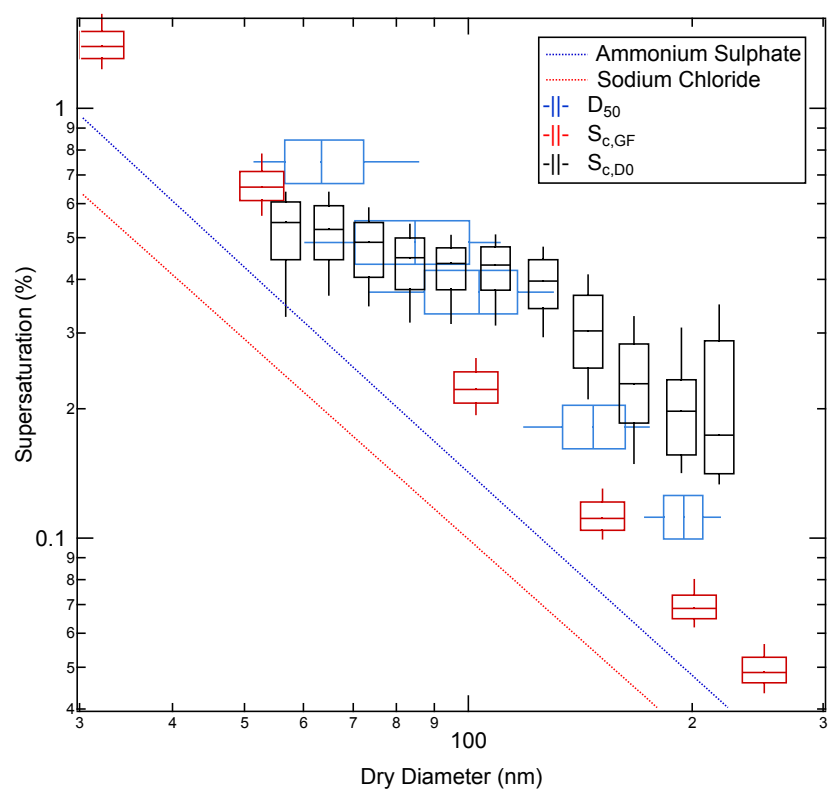

Fig. 7. Critical supersaturation vs. dry diameter for the HTDMA results predicted using the $\kappa$ model, CCNc results using both derived $S_{\mathrm{c}, \mathrm{D} 0}$ and derived $D_{50, \mathrm{~S}}$. The centreline of the box represents the median of the data, with the box edges representing the $25 \%$ and $75 \%$ quartiles and the whiskers the $10 \%$ and $90 \%$ quartiles. The dashed lines show the results of the ADDEM model (Topping et al., 2005) for inorganic salt particles.

particle activation behaviour, which can be derived from HTDMA and $\mathrm{CCNc}$ measurements:

$S=\frac{\mathrm{GF}_{\mathrm{D} 0, \mathrm{RH}}^{3}-1}{\mathrm{GF}_{\mathrm{D} 0, \mathrm{RH}^{3}-(1-\kappa)}} \exp \left(\frac{4 \sigma_{w} M_{\mathrm{W}}}{\mathrm{RT} \rho_{\mathrm{w}} D_{0} \mathrm{GF}_{\mathrm{D} 0, \mathrm{RH}}}\right)$

where $\mathrm{GF}_{\mathrm{D}_{0}, \mathrm{RH}}$ is the growth factor at a given dry diameter, $D_{0}$, and relative humidity, RH. Equation (2) was used to calculate $\kappa$ for both HTDMA and CCNc measurements in the same manner as shown by Irwin et al. (2010), with instrumental uncertainties arithmetically propagated through to the final data products of critical supersaturation, threshold dry diameter for activation and number of $\mathrm{CCN}$.

Figure 7 directly compares HTDMA and $\mathrm{CCNc}$ derived critical supersaturations. Critical supersaturation retrieved from the S-step interpretated CCNc data (i.e. derived $S_{\mathrm{c}, \mathrm{D} 0}$ ) has been plotted against dry diameter as has the critical supersaturation calculated from Eq. (2) using HTDMA corrected mean growth factor derived $\kappa_{\mathrm{GF}}$. Finally, using D-step $\mathrm{CCNc}$ data analysis, $D_{50, \mathrm{~S}}$ has been plotted against the corresponding corrected CCNc setpoint supersaturation. The predicted critical supersaturation from the HTDMA measurements (shown in red) clearly shows a consistently more hygroscopic aerosol than that derived from either $\mathrm{CCNc}$ technique. The D-step analysis (the dry diameter for activation at each supersaturation setting; of which there are 5) shows a typically less hygroscopic aerosol than measured and derived 


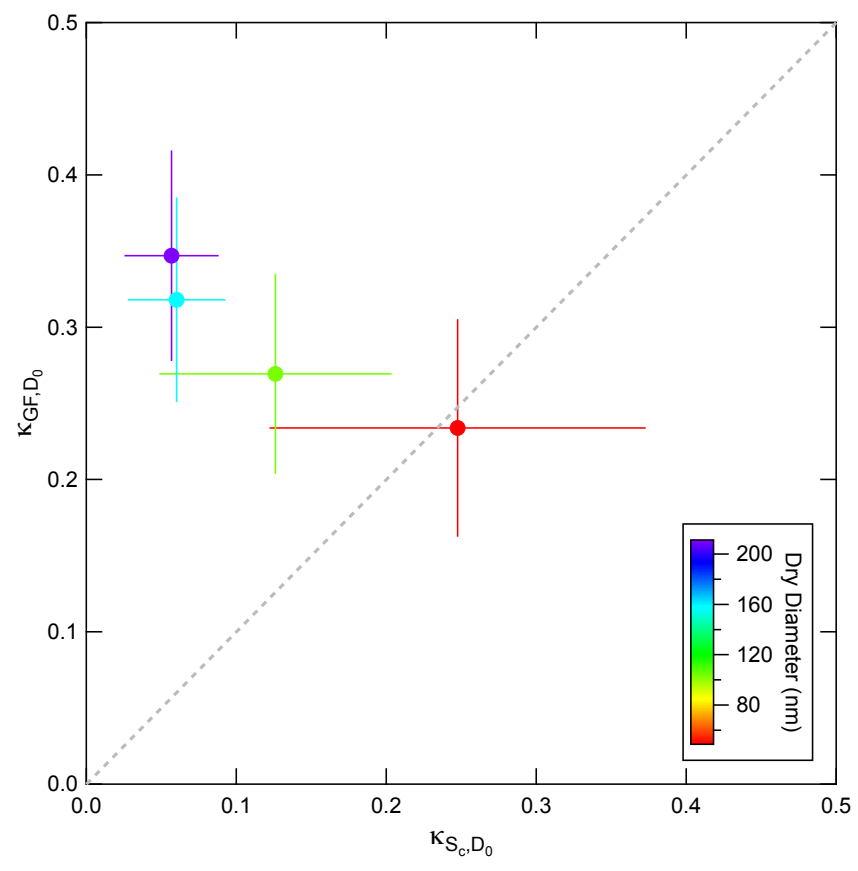

Fig. 8. $\kappa_{\mathrm{GF}, \mathrm{D} 0}$ as measured from the HTDMA vs. $\kappa_{\mathrm{Sc}, \mathrm{D} 0}$ as measured by the $\mathrm{CCNc}$, as a function of dry diameter. Note, the $\mathrm{CCNc}$ diameters are not on the same diameter base and have been binned as described in the main text.

by the HTDMA analysis. The CCNc S-step analysis shows a larger variation in critical supersaturation as a function of particle dry diameter than for either of the other two derivations, though there is good overlap between $\mathrm{CCNc}$ derivation techniques in the $70 \mathrm{~nm}-100 \mathrm{~nm}$ size range. The disagreement between $D_{50, \mathrm{~S}}$ and $S_{\mathrm{c}, \mathrm{D} 0}$ is most prominent at the edges of the dry diameter and/or supersaturation ranges. This may be attributed to the limitations, and thus increased uncertainty, of deriving these products in such close proximity to the edges of the instrument range (see Figs. S2 and S3 in Supplement). It should be noted that the overall standard error in $D_{50, \mathrm{~S}}$ is smaller over the $\mathrm{CCNc}$ measurement range than for $S_{\mathrm{c}, \mathrm{D} 0}$.

The hygroscopicity parameter $\kappa$ has been calculated for both HTDMA and CCNc data using Eq. (2). As the SMPS supplying the CCN did not measure at the same dry diameters as the HTDMA, the CCNc dry diameters have been binned around each HTDMA dry diameter, using $\sqrt{D_{0} \cdot D_{1}}$ for the lower bin edge and $\sqrt{D_{1} \cdot D_{2}}$ for the upper bin edge. The mean and standard deviation of $\kappa_{\mathrm{Sc}}$ was calculated for each size bin, and plotted against mean $\kappa_{\mathrm{GF}}$, shown in Fig. 8 . Values of $\kappa_{\mathrm{GF}}$ tend to increase with particle size, whereas conversely, values of $\kappa_{\mathrm{Sc}}$ tend to decrease with particle size. Though there is a large standard deviation for the smallest dry diameter bin $\left(41 \mathrm{~nm}<D_{0}<74 \mathrm{~nm}\right)$, there is reasonable agreement seen between the instruments. The observed increase in the difference between values of $\kappa$ with dry diame-

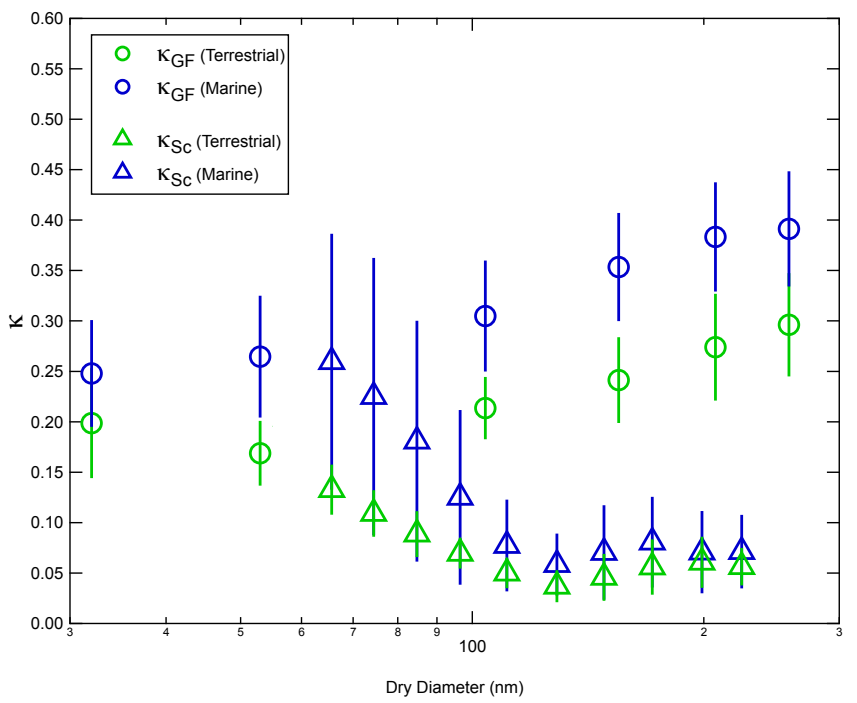

Fig. 9. $\kappa$ vs. dry diameter, for the CCNc (triangles) and HTDMA (circles) measurements, both for Terrestrial (green) and Marine (blue) sectors.

ter though non-intuitive could be due to differences in equilibrium states in the two instruments (discussed below). For example, larger particles could contain more semi-volatile material than smaller particles, and should the equilibrium conditions differ between instruments (which they will), the final organic content may differ as constituents are preferentially volatilised in different ratios in each instrument. Furthermore, the non-idealality of the solution (i.e. activity coefficient) might change significantly between $90 \% \mathrm{RH}$ and the point of activation, and the Kelvin term may not be accurately represented assuming the surface tension is equal to that of water.

$\kappa_{\mathrm{GF}}$ (circles) and $\kappa_{\mathrm{Sc}}$ (triangles) were plotted for both Marine (blue) and Terrestrial (green) sectors against particle dry diameter (Fig. 9). The aerosol water uptake is typically evaluated to be lower when calculated from $\mathrm{CCNc}$ data than from HTDMA measurements and the derived $\kappa_{\mathrm{Sc}}$ values are much smaller than those of $\kappa_{\mathrm{GF}}$. The latter values are frequently in the 0.2-0.3 range, and the majority of data are within the range observed in previous studies of rainforest CCN (Gunthe et al., 2009; range 0.05-0.45 using $\mathrm{CCNc}$ derived hygroscopicity).

A possible cause of the discrepancies between the values of $\kappa_{\mathrm{Sc}}$ and $\kappa_{\mathrm{GF}}$ could be due to instrumental differences rather than a fault with the model. The size-selection process involves drying the aerosol prior to entry into a DMA; any differences in the initial drying of the aerosol prior to size-selection will determine the water content in the particle and gaseous phase (air surrounding the particle) as the particle airflow strives to reach equilibrium. Furthermore, any volatile or semi-volatile compounds can start to evaporate from the aqueous phase to the gaseous phase. Therefore, 
the resultant aerosol sample flow is a mix of relatively dry particulate matter, water vapour and other semi-volatile compounds (inorganic and organic). After some time (circa $1 \mathrm{~h}$; and assuming the composition does not change with time), this aerosol sample flow will reach equilibrium with the sheath flow of the DMA, with similar amounts of components in the gaseous phase. Differences in both aerosol composition (from marine and terrestrial air masses) and instrumental sampling (differing rates and degrees of drying/wetting) could increase this inconsistency.

As neither drying system will dry to $0 \% \mathrm{RH}$, the resultant particle dry diameter will be larger than the completely dry particle diameter and, for example, in terms of HTDMA measurements, would result in a lower measured growth factor even if equilibrium is reached in the humidification section (due to the small overestimation of $D_{0}$ ). This behaviour has been shown previously by the multi-site study of Aklilu et al. (2006), where data from one HTDMA was successfully reconciled with the AMS (using the Zdanovskii, Stokes and Robinson mixing rule; Stokes and Robinson, 1966), with all components accounted for, whereas for the other HTDMA, it was necessary to excluded nitrate in order to achieve reconciliation. Furthermore, Gysel et al. (2007) reconciled HTDMA and AMS data using ZSR within uncertainty except for times of elevated nitrate concentrations, and Prenni et al. (2001) have shown similar behaviour for semi-volatile compounds. Mikhailov et al. (2004) have also shown this evaporative loss to occur as a function of $\mathrm{RH}$ giving rise to errors in dry particle size on the order of several nanometers, and so the potential differences in initial sizing between instruments, though speculative, cannot be overlooked.

Further to size-selection, the relative amounts of gaseous and aqueous compounds in the aerosol sample flow stream will likely differ between different instrument sections, due to changes in the kinetics and the resultant departure from equilibrium. The $\mathrm{CCNc}$ has a scrubber which will remove volatile and semi-volatile compounds from the sheath flow, which is absent from the HTDMA's recirculating sheath. Therefore the relative amounts of liquid water and water vapour, in addition to SVOC in both aqueous and gaseous phases, will be different in the humidification sections of both instruments.

\subsection{Calculation of the number of Cloud Condensation Nuclei}

Using values of $\kappa$, Eq. (2) can be used to calculate the threshold dry diameter for activation $\left(D_{\text {thres }}\right)$ for HTDMA mean corrected growth factor data. Furthermore, the physical threshold dry diameter for activation can be directly derived from the $\mathrm{CCNc}$ data via two additional pathways (bypassing the need for $\kappa$ ); directly from D-step interpreted data, $D_{50, \mathrm{~S}}$, or by plotting $S_{\mathrm{c}}-S_{\text {set }}$ vs. $D_{0}$ where the intercept is interpreted as the physical threshold dry diameter (as shown by Fig. S6 in the Supplement). In order to calcu- late $N_{\mathrm{CCN}}$, the DMPS number-size distribution is integrated using the trapezium rule between the largest dry diameter $(\sim 700 \mathrm{~nm})$ and the threshold dry diameter for activation from each method. Figure 10 shows the results of this analysis from a variety of different methods. Figure 10a shows $N_{\mathrm{CCN}}$ calculated from the threshold dry diameter as derived by the $\kappa_{\mathrm{GF}} \mathrm{vs}$ the threshold dry diameter for activation derived from the critical supersaturation (bypassing kappa). Best agreement is at $0.48 \%$, the errors in the $S_{\mathrm{c}, \mathrm{D} 0}$ derived $N_{\mathrm{CCN}}$ are larger than that for the HTDMA, with noticeable disagreement in the low $S$, low $N$ regime.

Figure 10b shows $N_{\mathrm{CCN}}$ calculated from S-step analysis (without $\kappa$ ) vs. $N_{\mathrm{CCN}}$ calculated from D-step analysis (again, without $\kappa$ ). As expected, theres a smaller error associated with $N_{\mathrm{CCN}}$ derived using D-step interpreted data, compared to that of S-step interpreted data; as fewer analysis steps have been taken, and $\mathrm{D}$-step analysis fits a sigmoidal function to more $\mathrm{x}$-axis data points (see the uncertainty associated with each method in Figs. S2 and S3 in the Supplement). Again, best agreement is observed at a supersaturation of $0.48 \%$, but there is relatively good agreement throughout the $S$ range. The reason that the lower and upper supersaturations, $S_{\text {set0 }}$ and $S_{\text {set4 }}$ respectively, are not included is that this method of calculating $N_{\mathrm{CCN}}\left(S_{\mathrm{c}, \mathrm{D} 0}\right)$ uses the physical threshold dry diameter of the aerosol as described by plotting $S_{\mathrm{c}}-S$ vs. $D_{0}$ where the intercept for a given $S$ is the threshold dry diameter, and it is not possible to derive $S_{\mathrm{c}, \mathrm{D} 0}$ outside of the $S$ range.

Figures 10c and 11 (and Fig. S7 in the Supplement) show the comparison between $N_{\mathrm{CCN}}$ derived from the HTDMA

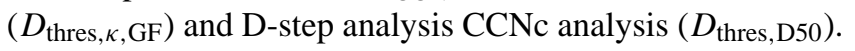
The HTDMA data predicts higher numbers of $\mathrm{CCN}$ than data from the $\mathrm{CCNc}$ would suggest. Previous studies using these instruments (e.g. Irwin et al., 2010), have shown the converse to be true (i.e. that $N_{\mathrm{CCN}}$ is underpredicted from HTDMA measurements). The largest difference between the two results however, is in the low $N$, low $S$ regime. The HTDMA does consistently over predict $N_{\mathrm{CCN}}$ when compared to $N_{\mathrm{CCN}}$ derived from D-step analysis, as a result of the HTDMA apparently measuring an aerosol with a higher water affinity than as reported from the CCNc.

Data were fitted with an ODR line function, the results of which are shown in Table 2. Of the two different $N_{\mathrm{CCN}}$ comparisons between instruments, the $D_{\text {thres, } \kappa \text {, GF }}$ vs. $D_{\text {thres, D50 }}$ method (shown in Fig. 10c) shows considerably less deviation from the 1:1 line, though with increased scatter (denoted by $R^{2}$ ), compared to data derived from $D_{\text {thres, } S_{\mathrm{c}}}$.

In contrast to the data presented here, the measurements performed in the Amazon described by Roberts et al. (2001), report $N_{\mathrm{CCN}}$ concentrations between $33-320 \mathrm{~cm}^{-3}$ for the range $0.15 \%-1 \%$ supersaturation, which is lower than any of the $N_{\mathrm{CCN}}$ predictions made with size-resolved aerosol water uptake measurements in this study. Size-resolved water uptake measurements from Amazonia as reported by Gunthe et al. (2009) predict $N_{\mathrm{CCN}}$ to be between 10 and $500 \mathrm{~cm}^{-3}$ 
a)
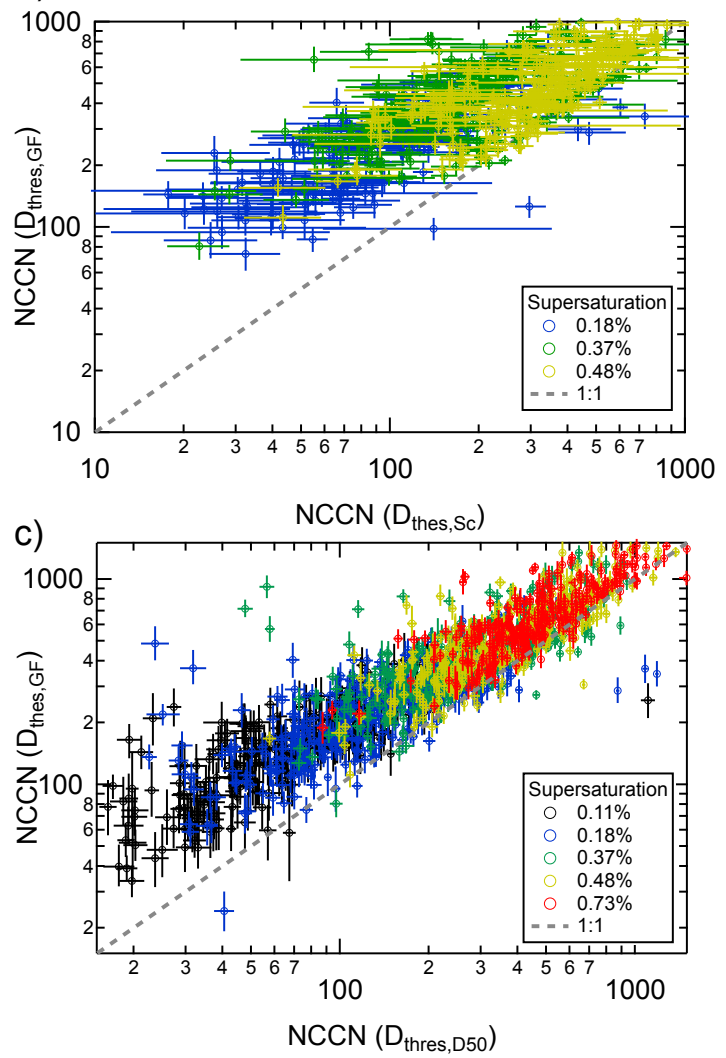

b)

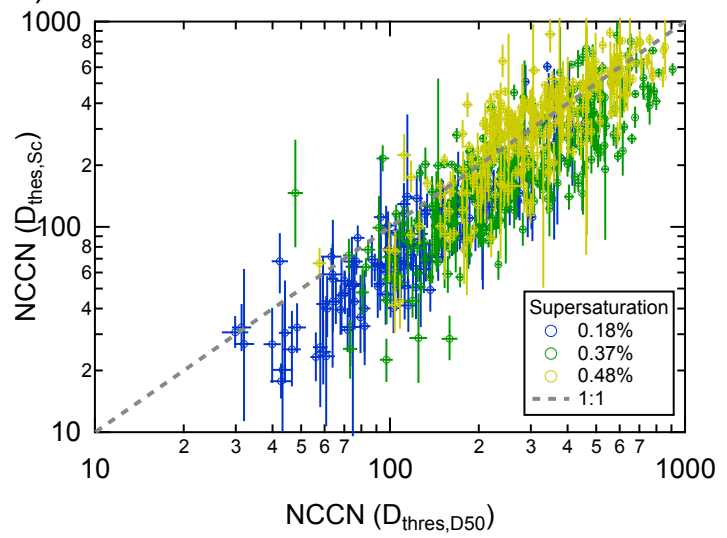

Fig. 10. $N_{\mathrm{CCN}}$ vs. $N_{\mathrm{CCN}}$ for: (a) HTDMA vs. CCNc S-step analysis; (b) CCNc S-step analysis vs. CCNc D-step analysis; (c) HTDMA vs. CCNc D-step analysis.

Table 2. A table of ODR slopes and $R^{2}$ for straight line fits to $N_{\mathrm{CCN}}$ derived from $D_{\text {thres, } \kappa, \mathrm{GF}}$ vs. $D_{\text {thres, } S_{\mathrm{c}}}$ and $D_{\text {thres, } \kappa, \mathrm{GF}}$ vs. $D_{\text {thres,D50. }}$

\begin{tabular}{cccccc}
\hline \multicolumn{3}{c}{ GF vs. $S_{\mathrm{c}}$} & & \multicolumn{3}{c}{ GF vs. $D_{50}$} \\
$S_{\text {set }}$ & Slope & $R^{2}$ & $S_{\text {set }}$ & Slope & $R^{2}$ \\
\hline 0.11 & & & 0.11 & 1.2847 & 0.26 \\
0.18 & 1.5163 & 0.35 & 0.18 & 1.1945 & 0.41 \\
0.37 & 1.6752 & 0.38 & 0.37 & 1.3289 & 0.55 \\
0.48 & 1.3437 & 0.65 & 0.48 & 1.2717 & 0.68 \\
0.73 & & & 0.73 & 1.2884 & 0.69 \\
\hline
\end{tabular}

for the supersaturation range $0.10 \%$ to $0.82 \%$, indicating differences in the aerosol over Bornean and the Amazonian rainforests.

\section{Discussion}

In this paper we present the first hygroscopicity study in an Asian rainforest and attempt to reconcile the HTDMA/CCNc data with the use of the popular $\kappa$-Köhler model. This pa- per also marks the first size-resolved particle water uptake measurements made in this region, with interpretation of the data aided through the use of a back trajectory cluster analysis. The $\kappa_{\mathrm{Sc}}$ range was typically $0.05-0.37$ for the measured dry diameter and supersaturation ranges of $50-210 \mathrm{~nm}$ and $0.11-0.73 \%$ respectively. In comparison, the $\kappa_{\mathrm{GF}}$ range was typically $0.17-0.37$ for the dry diameter range $32-258 \mathrm{~nm}$ measured at $90 \% \mathrm{RH}$. This compares with the $\kappa$ range of $0.05-0.45$ for the dry diameter range $40-240 \mathrm{~nm}$ and supersaturation range $0.10-0.82 \%$ found in the Amazon (Gunthe et al., 2009).

The aerosol number-size distributions are significantly different during the Terrestrial periods than the Marine, indicating multimodal behaviour and hence also possible external mixing. Sub-saturated water uptake measurements from the HTDMA at $90 \%$ showed the aerosol to comprise a variety of growth factors at each size, with a less hygroscopic mode around 1.1 in $p(\mathrm{GF})$, becoming more prominent with increasing aerosol size. Though the size-resolved aerosol composition data as measured by the AMS could not provide adequate information regarding the composition of particles for a given dry diameter, periods of high organic content (attributed to be that of Terrestrial origin by the back trajectory 
a)

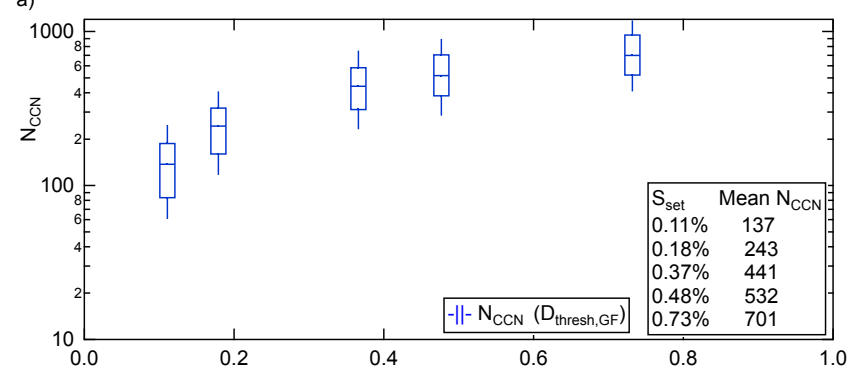

b)

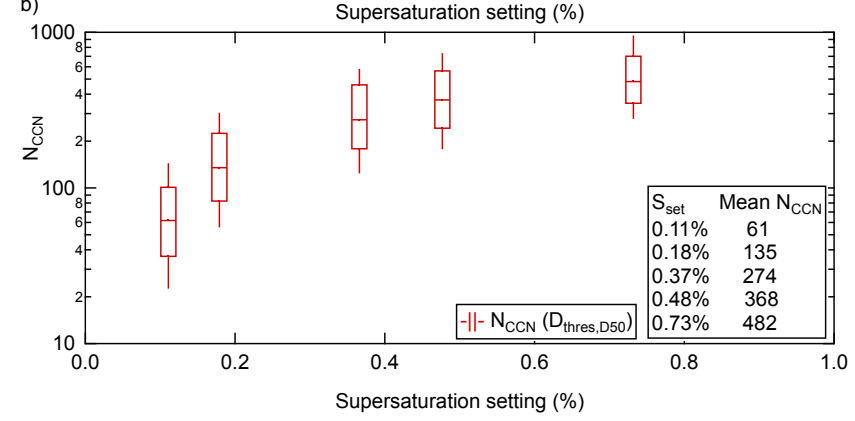

Fig. 11. $N_{\mathrm{CCN}}$ vs. $S_{\text {set }}$ for (a) as derived from HTDMA data and (b) derived from CCNc D-step analysis. The tables show the mean $N_{\mathrm{CCN}}$ concentrations at each supersaturation.

analysis) are characterised by a lower overall hygroscopicity at all sizes, with the Marine sector accounting for the more hygroscopic time periods.

Supersaturated measurements show a departure from the typical monotonic trend typically shown by the fraction of aerosol activated, $F_{\mathrm{A}}\left(\mathrm{S}, \mathrm{D}_{0}\right)$, most notably at the higher supersaturations $\left(S_{\text {set }}>0.37 \% \mathrm{~S}\right)$ and smaller dry diameters $\left(D_{0}<120 \mathrm{~nm}\right)$. The apparent complexity of the mixing state as illustrated by HTDMA measurements, is likely to manifest itself in the CCNc measurements as a source of uncertainty, though screening the data for periods of external mixing couldn't explain the discrepancies as the variation in activation data is much greater than the differences between screened and unscreened data. The greatest level of uncertainty from the $\mathrm{CCNc}$ measurements was attributed to the $\mathrm{S}$-step analysis, and as such the D-step analysis is the recommended analysis pathway for this particular dataset.

Though near-identical calibrations were performed for each instrument at each location, there are significant differences between the all results shown by the two marine campaigns presented by Good et al. (2010a,b). Good et al. (2010a) present data from a marine location, where on average the $\kappa$ values from the $\mathrm{CCNc}$ are higher than those derived from the HTDMA, yet another marine study by Good et al. (2010b) shows NCCN (and $\kappa$ ) derived from the CCNc to be near-systematically underpredicted. The results can be compared to similar measurements made during the Convective and Orographically-induced Precipitation Study (COPS; Irwin et al., 2010) in Germany's Blackforest, during the sum- mer of 2007. Values of $\kappa_{\mathrm{Sc}}$ from moderately-polluted COPS were between 0.4 and 0.1 and values of $\kappa_{\mathrm{GF}}$ were between 0.2 and 0.08 , the reverse of the results from this project; where values for the HTDMA-derived hygroscopicity parameter were larger than when derived from $\mathrm{CCNc}$ measurements. The consequence is that the results from COPS predicted $N_{\mathrm{CCN}}$ from HTDMA measurements to be lower than from CCNc measurements. The data from COPS typically consisted of $N_{\mathrm{CCN}}$ slopes closer to the 1:1 line, and higher $R^{2}$ correlation. Furthermore, typical values of $N_{\mathrm{CCN}}$ during COPS were 3-4 times those calculated during OP3, leading to the conclusion that aerosol in the tropical region of Borneo can be considered to be a synthesis of marine and continental aerosol traits, in a biogenically diverse setting. Due to the climatic importance of the tropical regions, and the apparent variability of various derived data products, such as $\kappa$, between regions, any anthropogenic perturbations to aerosol number and composition due to changes in land use in the tropics highlight the importance of studies of this type.

\section{Conclusions}

Size-resolved HTDMA and CCNc measurement of atmospheric aerosol in Borneo identified the aerosol to comprise a range of compositions over the measured size range $\left(D_{0}=32-258 \mathrm{~nm}\right)$, and for the aerosol hygroscopicity to vary with changing air mass back trajectories, largely outside of uncertainty.

Reconciliations of the results from both instruments was performed through to predictions of $N_{\mathrm{CCN}}$, where good agreement is seen between the HTDMA and CCN derived products. The HTDMA typically sees a more hygroscopic aerosol throughout the campaign than the $\mathrm{CCNc}\left(\kappa_{\mathrm{GF}}=\right.$ $0.17-0.37$ compared to $\kappa_{S_{\mathrm{c}}}=0.05-0.37$ ), resulting in a higher predicted number of $\mathrm{CCN}$. However, both methods predict the overall $\mathrm{CCN}$ number concentration to be modest, which reinforces results from previous studies that suggest that rainforest aerosol may behave in a "marine" fashion (Roberts et al., 2001; Gunthe et al., 2009), though the predicted $N_{\mathrm{CCN}}$ results from the Amazon are typically lower, with values of $N_{\mathrm{CCN}}$ at $S=0.73 \%$ between 482 and $701 \mathrm{~cm}^{-3}$ for suband supersaturated measurement predictions respectively, in contrast to the much lower figures reported by Gunthe et al. (2009) $\left(\sim 163 \mathrm{~cm}^{-3}\right.$ at $\left.S=0.82 \%\right)$.

In order to combat the issues of mixing state in future measurements of this type, the authors recommend a higher resolution set of CCNc measurements, at a higher number of supersaturation setpoints. The increased number of diameter measurements with allow for a better analysis of the aerosol behaviour at each diameter, and a higher number of supersaturations will reduce the uncertainty involved in fitting the data for $S_{\mathrm{c}, \mathrm{D} 0}$ and $D_{50, \mathrm{~S}}$. In addition, any improvements in the measurement of aerosol size-resolved composition would be welcomed greatly, as it would enable an in depth analysis 
of aerosol composition and its influence on hygroscopicity as a function of particle dry diameter (the AMS was not suitable on this occasion due to insufficient particle mass).

\section{Supplement related to this article is available online at: http://www.atmos-chem-phys.net/11/11157/2011/ acp-11-11157-2011-supplement.pdf.}

Acknowledgements. The Oxidant and Photochemical Particle Processes above a Southeast Asian tropical rainforest project (OP3) was funded by the National Environmental Research Council (NERC; NE/0021171/1). The authors wish to thank the Malaysian and Sabah Governments for their permission to conduct research in Malaysia; the Malaysian Meteorological Department for access to the Bukit Atur Global Atmosphere Watch station; Waidi Sinun of Yayasan Sabah and Glen Reynolds of the Royal Societys South East Asian Rain Forest Research Programme for logistical support at the Danum Valley Research Station and the all Royal Society research assistants. Special thanks to J. Dorsey, K. Bower, M. Flynn, P. Williams for their help in the field. This work was also made possible with the Ph.D studentship of Martin Irwin (NER/S/A/2006/14036). This is paper 526 of the Royal Society's South-East Asian Rainforest Research Programme.

Edited by: R. MacKenzie

\section{References}

Aklilu, Y., Mozurkewich, M., and Prenni, A.: Hygroscopicity of particles at two rural, urban influenced sites during Pacific 2001: Comparison with estimates of water uptake from particle composition, Atmos. Environ., 40, 2650-2661, 2006.

Albrecht, B.: Aerosols, cloud microphysics, and fractional cloudiness, Science, 245, 1227-1230, 1989.

Allan, J. D., Jimenez, J. L., Williams, P. I., Alfarra, M. R., Bower, K. N., Jayne, J. T., Coe, H., and Worsnop, D. R.: Quantitative sampling using an Aerodyne aerosol mass spectrometer 1. Techniques of data interpretation and error analysis, J. Geophys. Res., 108, 4090, doi:10.1029/2002JD002358, 2003.

Allan, J. D., Alfarra, M. R., Bower, K. N., Coe, H., Jayne, J. T., Worsnop, D. R., Aalto, P. P., Kulmala, M., Hyötyläinen, T., Cavalli, F., and Laaksonen, A.: Size and composition measurements of background aerosol and new particle growth in a Finnish forest during QUEST 2 using an Aerodyne Aerosol Mass Spectrometer, Atmos. Chem. Phys., 6, 315-327, doi:10.5194/acp-6-315-2006, 2006.

Andreae, M. and Rosenfeld, D.: Aerosol-cloud-precipitation interactions. Part 1. The nature and sources of cloud-active aerosols, Earth Sci. Rev., 89, 13-41, 2008.

Andreae, M., Rosenfeld, D., Artaxo, P., and Costa, A.: Smoking rain clouds over the Amazon, Science, 303, 1337-1342, 2004.

BADC: European Centre for Medium-Range Weather Forecasts. ECMWF Trajectories, Internet, available online at: http://badc. nerc.ac.uk/data/ecmwf-trj/, 2009.

Broekhuizen, K., Chang, R. Y.-W., Leaitch, W. R., Li, S.-M., and Abbatt, J. P. D.: Closure between measured and modeled cloud condensation nuclei (CCN) using size-resolved aerosol composi- tions in downtown Toronto, Atmos. Chem. Phys., 6, 2513-2524, doi:10.5194/acp-6-2513-2006, 2006.

Canagaratna, M. R., Jayne, J. T., Jimenez, J. L., Allan, J. D., Alfarra, M. R., Zhang, Q., Onasch, T. B., Drewnick, F., Coe, H., Middlebrook, A., Delia, A., Williams, L. R., Trimborn, A. M., Northway, M. J., Decarlo, P. F., Kolb, C. E., Davidovits, P., and Worsnop, D. R.: Chemical and microphysical characterization of ambient aerosols with the aerodyne aerosol mass spectrometer, Mass spectrom. Rev., 26, 185-222, 2007.

Chen, Q., Farmer, D., Schneider, J., and Zorn, S.: Mass spectral characterization of submicron biogenic organic particles in the Amazon Basin, Geophys. Res. Lett., 36, 2009.

Chuang, P. Y., Collins, D. R., Pawlowska, H., Snider, J. R., Jonsson, H. H., Brenguier, J.-L., Flagan, R. C., and Seinfeld, J. H.: CCN measurements during ACE-2 and their relationship to cloud microphysical properties, Tellus B, 52, 843-867. doi:10.1034/j.1600-0889.2000.00018.x, 2000.

Claeys, M., Graham, B., Gyorgy, V., Wang, W., Vermeylen, R., Pashynska, V., Cafmeyer, J., Guyon, P., Meinrat, O., Artaxo, P., and Maenhaut, W.: Formation of Secondary Organic Aerosols Through Photooxidation of Isoprene, Science, 303, 1173-1176, 2004.

Cross, E. S., Slowik, J. G., Davidovits, P., Allan, J. D., Worsnop, D. R., Jayne, J. T., Lewis, D. K., Canagaratna, M., and Onasch, T. B.: Laboratory and ambient particle density determinations using light scattering in conjunction with aerosol mass spectrometry, Aerosol Sci. Technol., 41, 343-359, 2007.

Cubison, M. J., Coe, H., and Gysel, M.: A modified hygroscopic tandem DMA and a data retrieval method based on optimal estimation, J. Aerosol Sci., 36, 846-865, 2005.

DeCarlo, P., Kimmel, J., Trimborn, A., Northway, M., Jayne, J., Aiken, A., Gonin, M., Fuhrer, K., Horvath, T., Docherty, K., Worsnop, D., and Jimenez, J. L.: Field-Deployable, HighResolution, Time-of-Flight Aerosol Mass Spectrometer, Anal. Chem., 78, 8281-8289, 2006.

Duplissy, J., Gysel, M., Alfarra, M., Dommen, J., Metzger, A., Prevot, A., Weingartner, E., Laaksonen, A., Raatikainen, T., and Good, N.: Cloud forming potential of secondary organic aerosol under near atmospheric conditions, Geophys. Res. Lett., 35, L03818, doi:10.1029/2007GL031075, 2008.

Dusek, U., Frank, G., Curtius, J., Drewnick, F., Schneider, J., Kürten, A., Rose, D., Andreae, M. O., Borrmann, S., and Pöschl, U.: Enhanced organic mass fraction and decreased hygroscopicity of cloud condensation nuclei $(\mathrm{CCN})$ during new particle formation events, Geophys. Res. Lett., 37, L03804, doi:10.1029/2009GL040930, 2010.

Ervens, B., Cubison, M. J., Andrews, E., Feingold, G., Ogren, J. A., Jimenez, J. L., Quinn, P. K., Bates, T. S., Wang, J., Zhang, Q., Coe, H., Flynn, M., and Allan, J. D.: CCN predictions using simplified assumptions of organic aerosol composition and mixing state: a synthesis from six different locations, Atmos. Chem. Phys., 10, 4795-4807, doi:10.5194/acp-10-4795-2010, 2010.

Facchini, M. C., Decesari, S., Mircea, M., Fuzzi, S., and Loglio, G.: Surface tension of atmospheric wet aerosol and cloud/fog droplets in relation to their organic carbon econtent and chemical composition, Atmos. Environ., 33, 4853-4857, 2000.

Feichter, J., Roeckner, E., and Lohmann, U.: Nonlinear aspects of the climate response to greenhouse gas and aerosol forcing, J. Clim., 17, 2384-2398, 2004. 
Forster, P., Ramaswamy, V., Artaxo, P., Berntsen, T., Betts, R., Fahey, D., Haywood, J., Lean, J., Lowe, D., Myhre, G., Nganga, J., Prinn, R., Raga, G., Schulz, M., and Dorland, R. V.: Changes in Atmospheric Constituents and in Radiative Forcing. In: Climate Change 2007: The Physical Science Basis, Contribution of Working Group I to the Fourth Assessment Report of the Intergovernmental Panel on Climate Change, Cambridge, UK and New York, NY, USA, 153-203, 2007.

Freud, E., Ström, J., Rosenfeld, D., and Tunved, P.: Anthropogenic aerosol effects on convective cloud microphysical properties in southern Sweden, Tellus B, 60, 286-297, 2008.

Goldstein, A. and Galbally, I.: Known and unexplored organic constituents in the earth's atmosphere, Environ. Sci. Technol., 2007.

Good, N., Coe, H., and McFiggans, G.: Instrumentational operation and analytical methodology for the reconciliation of aerosol water uptake under sub- and supersaturated conditions, Atmos. Meas. Tech., 3, 1241-1254, doi:10.5194/amt-3-12412010, 2010a.

Good, N., Topping, D., Allan, J., Flynn, M., Fuentes, E., Irwin, M., Williams, P., Coe, H., and McFiggans, G.: Consistency between parameterisations of aerosol hygroscopicity and $\mathrm{CCN}$ activity during the RHaMBLe Discovery cruise, Atmos. Chem. Phys., 10, 3189-3203, doi:10.5194/acp-10-3189-2010, 2010 b.

Good, N., Topping, D. O., Duplissy, J., Gysel, M., Meyer, N. K., Metzger, A., Turner, S. F., Baltensperger, U., Ristovski, Z., Weingartner, E., Coe, H., and McFiggans, G.: Widening the gap between measurement and modelling of secondary organic aerosol properties?, Atmos. Chem. Phys., 10, 2577-2593, doi:10.5194/acp-10-2577-2010, 2010c.

Gunthe, S., King, S., Rose, D., Chen, Q., Roldin, P., Farmer, D., Jimenez, J., Artaxo, P., and Aneae, M.: Cloud condensation nuclei in pristine tropical rainforest air of Amazonia: size-resolved measurements and modeling of atmospheric aerosol composition and CCN activity, Atmos. Chem. Phys., 9, 7551-7575, doi:10.5194/acp-9-7551-2009, 2009.

Gysel, M., Crosier, J., Topping, D. O., Whitehead, J., Bower, K. N., Cubison, M. J., Williams, P. I., Flynn, M. J., McFiggans, G. B., and Coe, H.: Closure study between chemical composition and hygroscopic growth of aerosol particles during TORCH2, Atmos. Chem. Phys., 7, 6131-6144, doi:10.5194/acp-7-6131-2007, 2007.

Gysel, M., McFiggans, G., and Coe, H.: Inversion of tandem differential mobility analyser (TDMA) measurements, J. Aerosol Sci., 40, 134-151, 2009.

Hallquist, M., Wenger, J. C., Baltensperger, U., Rudich, Y., Simpson, D., Claeys, M., Dommen, J., Donahue, N. M., George, C., Goldstein, A. H., Hamilton, J. F., Herrmann, H., Hoffmann, T., Iinuma, Y., Jang, M., Jenkin, M., Jimenez, J. L., Kiendler-Scharr, A., Maenhaut, W., McFiggans, G., Mentel, T. F., Monod, A., Prévôt, A. S. H., Seinfeld, J. H., Surratt, J. D., Szmigielski, R., and Wildt, J.: The formation, properties and impact of secondary organic aerosol: current and emerging issues, Atmos. Chem. Phys., 9, 5155-5236, doi:10.5194/acp-9-5155-2009, 2009.

Henze, D. K. and Seinfeld, J. H.: Global secondary organic aerosol from isoprene oxidation, Geophys. Res. Lett., 33, L09812, doi:10.1029/2006GL025976, 2006.

Hewitt, C. N., Lee, J. D., Mackenzie, A. R., Barkley, M. P., Carslaw, N., Carver, G. D., Chappell, N. A., Coe, H., Collier, C., Commane, R., Davies, F., Davison, B., Dicarlo, P.,
Di Marco, C. F., Dorsey, J. R., Edwards, P. M., Evans, M. J., Fowler, D., Furneaux, K. L., Gallagher, M., Guenther, A., Heard, D. E., Helfter, C., Hopkins, J., Ingham, T., Irwin, M., Jones, C., Karunaharan, A., Langford, B., Lewis, A. C., Lim, S. F., Macdonald, S. M., Mahajan, A. S., Malpass, S., McFiggans, G., Mills, G., Misztal, P., Moller, S., Monks, P. S., Nemitz, E., Nicolas-Perea, V., Oetjen, H., Oram, D. E., Palmer, P. I., Phillips, G. J., Pike, R., Plane, J. M. C., Pugh, T., Pyle, J. A., Reeves, C. E., Robinson, N. H., Stewart, D., Stone, D., Whalley, L. K., and Yin, X.: Overview: oxidant and particle photochemical processes above a south-east Asian tropical rainforest (the OP3 project): introduction, rationale, location characteristics and tools, Atmos. Chem. Phys., 10, 169-199, doi:10.5194/acp-10169-2010, 2010.

Irwin, M., Good, N., Crosier, J., Choularton, T. W., and McFiggans, G.: Reconciliation of measurements of hygroscopic growth and critical supersaturation of aerosol particles in Southwest Germany, Atmos. Chem. Phys., 10, 11737-11752, doi:10.5194/acp10-11737-2010, 2010.

Jayne, J., Leard, D., and Zhang, X.: Development of an aerosol mass spectrometer for size and composition analysis of submicron particles, Aerosol Sci. Technol., 33, 49-70, 2000.

Juranyi, Z., Gysel, M., Weingartner, E., Decarlo, P. F., Kammermann, L., and Baltensperger, U.: Measured and modelled cloud condensation nuclei number concentration at the high alpine site Jungfraujoch, Atmos. Chem. Phys., 10, 7891-7906, 2010, http://www.atmos-chem-phys.net/10/7891/2010/.

Kanakidou, M., Seinfeld, J. H., Pandis, S. N., Barnes, I., Dentener, F. J., Facchini, M. C., Van Dingenen, R., Ervens, B., Nenes, A., Nielsen, C. J., Swietlicki, E., Putaud, J. P., Balkanski, Y., Fuzzi, S., Horth, J., Moortgat, G. K., Winterhalter, R., Myhre, C. E. L., Tsigaridis, K., Vignati, E., Stephanou, E. G., and Wilson, J.: Organic aerosol and global climate modelling: a review, Atmos. Chem. Phys., 5, 1053-1123, doi:10.5194/acp-5-1053-2005, 2005.

Köhler, H.: The nucleus in and the growth of hygroscopic droplets, Trans. Faraday Soc., 32, 1152-1161, 1936.

Laaksonen, A., Kulmala, M., O’Dowd, C. D., Joutsensaari, J., Vaattovaara, P., Mikkonen, S., Lehtinen, K. E. J., Sogacheva, L., Dal Maso, M., Aalto, P., Petäjä, T., Sogachev, A., Yoon, Y. J., Lihavainen, H., Nilsson, D., Facchini, M. C., Cavalli, F., Fuzzi, S., Hoffmann, T., Arnold, F., Hanke, M., Sellegri, K., Umann, B., Junkermann, W., Coe, H., Allan, J. D., Alfarra, M. R., Worsnop, D. R., Riekkola, M. L., Hyötyläinen, T., and Viisanen, Y.: The role of VOC oxidation products in continental new particle formation, Atmos. Chem. Phys., 8, 2657-2665, doi:10.5194/acp-82657-2008, 2008.

Liu, P., Ziemann, P., and Kittelson, D.: Generating particle beams of controlled dimensions and divergence: I. Theory of particle motion in aerodynamic lenses and nozzle expansions, Aerosol Sci. Technol., 22, 293-313, 1995a.

Liu, P., Ziemann, P., and Kittelson, D.: Generating particle beams of controlled dimensions and divergence: II. Experimental evaluation of particle motion in aerodynamic lenses and nozzle expansions, Aerosol Sci. Technol., 22, 314-324, 1995 b.

Liu, P. S. K., Leaitch, W. R., Banic, C. M., Li, S. M., Ngo, D., and Megaw, W. J.: Aerosol observations at Chebogue Point during the 1993 North Atlantic Regional Experiment: Relationships among cloud condensation nuclei, size distribution, and chem- 
istry, J. Geophys. Res., 101, 28971-28990, 1996.

Lohmann, U. and Feichter, J.: Global indirect aerosol effects: a review, Atmos. Chem. Phys., 5, 715-737, doi:10.5194/acp-5-7152005, 2005.

Marcolli, C., Luo, B., , and Peter, T.: Mixing of the Organic Aerosol Fractions: Liquids as the Thermodynamically Stable Phases, J. Phys. Chem. A, 108, 2216-2224, 2004.

Matthew, B. M., Middlebrook, A., and Onasch, T.: Collection Efficiencies in an Aerodyne Aerosol Mass Spectrometer as a Function of Particle Phase for Laboratory Generated Aerosols, Aerosol Sci. Technol., 42, 884-898, 2008.

McFiggans, G., Alfarra, M., Allan, J., Bower, K., and Coe, H.: Simplification of the representation of the organic component of atmospheric particulates, Faraday Discuss., 130, 341-362, 2005.

McFiggans, G., Artaxo, P., Baltensperger, U., Coe, H., Facchini, M. C., Feingold, G., Fuzzi, S., Gysel, M., Laaksonen, A., Lohmann, U., Mentel, T. F., Murphy, D. M., O’Dowd, C. D., Snider, J. R., and Weingartner, E.: The effect of physical and chemical aerosol properties on warm cloud droplet activation, Atmos. Chem. Phys., 6, 2593-2649, doi:10.5194/acp-6-25932006, 2006.

Medina, J., Nenes, A., Sotiropoulou, R., and Cottrell, L.: Cloud condensation nuclei closure during the International Consortium for Atmospheric Research on Transport and Transformation 2004 campaign: Effects of size-resolved composition, J. Geophys. Res, 112, D10S31, doi:10.1029/2006JD007588, 2007.

Mikhailov, E., Vlasenko, S., Niessner, R., and Pöschl, U.: Interaction of aerosol particles composed of protein and salts with water vapor: hygroscopic growth and microstructural rearrangement, Atmos. Chem. Phys., 4, 323-350, doi:10.5194/acp-4-323-2004, 2004.

Petters, M. and Kreidenweis, S.: A single parameter representation of hygroscopic growth and cloud condensation nucleus activity, Atmos. Chem. Phys., 7, 1961-1971, doi:10.5194/acp-71961-2007, 2007.

Petzold, A. and Schönlinner, M.: Multi-angle absorption photometry - a new method for the measurement of aerosol light absorption and atmospheric black carbon, J. Aerosol Sci., 35, 421-441, 2004.

Prenni, A. J., DeMott, P. J., Kreidenweis, S. M., Sherman, D. E., Russell, L. M., and Ming, Y.: The effects of low molecular weight dicarboxylic acids on cloud formation, J. Phys. Chem. A, 105, 11240-11248, 2001.

Reutter, P., Su, H., Trentmann, J., Simmel, M., Rose, D., Gunthe, S. S., Wernli, H., Andreae, M. O., and Pöschl, U.: Aerosoland updraft-limited regimes of cloud droplet formation: influence of particle number, size and hygroscopicity on the activation of cloud condensation nuclei (CCN), Atmos. Chem. Phys., 9, 7067-7080, doi:10.5194/acp-9-7067-2009, 2009.

Rissler, J., Swietlicki, E., Zhou, J., Roberts, G., Andreae, M. O., Gatti, L. V., and Artaxo, P.: Physical properties of the submicrometer aerosol over the Amazon rain forest during the wetto-dry season transition - comparison of modeled and measured CCN concentrations, Atmos. Chem. Phys., 4, 2119-2143, doi:10.5194/acp-4-2119-2004, 2004.

Rissler, J., Vestin, A., Swietlicki, E., Fisch, G., Zhou, J., Artaxo, P., and Andreae, M.: Size distribution and hygroscopic properties of aerosol particles from dry-season biomass burning in Amazonia, Atmos. Chem. Phys., 6, 471-491, doi:10.5194/acp-6-471-2006,
2006.

Roberts, G., Andreae, M., Zhou, J., and Artaxo, P.: Cloud condensation nuclei in the Amazon Basin: "Marine" conditions over a continent, Geophys. Res. Lett., 28, 2807-2810, 2001.

Roberts, G., Artaxo, P., Zhou, J., Swietlicki, E., and Andreae, M.: Sensitivity of CCN spectra on chemical and physical properties of aerosol: A case study from the Amazon Basin, J. Geophys. Res. Atmos., 107, 8070, doi:10.1029/2001JD000583, 2002.

Roberts, G., Nenes, A., and Seinfeld, J.: Impact of biomass burning on cloud properties in the Amazon Basin, J. Geophys. Res., 108, 4062, doi:10.1029/2001JD000985, 2003.

Roberts, G. C. and Nenes, A.: A continuous-flow streamwise thermal-gradient $\mathrm{CCN}$ chamber for atmospheric measurements, Aerosol Sci. Technol., 39, 206-221, 2005.

Robinson, N. H., Newton, H. M., Allan, J. D., Irwin, M., Hamilton, J. F., Flynn, M., Bower, K. N., Williams, P. I., Mills, G., Reeves, C. E., McFiggans, G., and Coe, H.: Source attribution of Bornean air masses by back trajectory analysis during the OP3 project, Atmos. Chem. Phys., 11, 9605-9630, doi:10.5194/acp-11-96052011, 2011.

Rose, D., Nowak, A., Achtert, P., Wiedensohler, A., Hu, M., Shao, M., Zhang, Y., Andreae, M. O., and Pöschl, U.: Cloud condensation nuclei in polluted air and biomass burning smoke near the mega-city Guangzhou, China - Part 1: Size-resolved measurements and implications for the modeling of aerosol particle hygroscopicity and CCN activity, Atmos. Chem. Phys., 10, 33653383, doi:10.5194/acp-10-3365-2010, 2010.

Rose, D., Gunthe, S. S., Su, H., Garland, R. M., Yang, H., Berghof, M., Cheng, Y. F., Wehner, B., Achtert, P., Nowak, A., Wiedensohler, A., Takegawa, N., Kondo, Y., Hu, M., Zhang, Y., Andreae, M. O., and Poschl, U.: Cloud condensation nuclei in polluted air and biomass burning smoke near the megacity Guangzhou, China - Part 2: Size-resolved aerosol chemical composition, diurnal cycles, and externally mixed weakly CCN-active soot particles, Atmos. Chem. Phys., 11, 2817-2836, doi:10.5194/acp-11-2817-2011, 2011.

Snider, J., Guibert, S., Brenguier, J., and Putaud, J.: Aerosol activation in marine stratocumulus clouds: 2. Köhler and parcel theory closure studies, J. Geophys. Res, 108, 8629, doi:10.1029/2002JD002692, 2003.

Stokes, R. and Robinson, R.: Interactions in aqueous nonelectrolyte solutions. I. Solute-solvent equilibria, J. Phys. Chem., 70, 21262130, 1966.

Topping, D. O., McFiggans, G. B., and Coe, H.: A curved multicomponent aerosol hygroscopicity model framework: Part 1 - Inorganic compounds, Atmos. Chem. Phys., 5, 1205-1222, doi:10.5194/acp-5-1205-2005, 2005.

Tunved, P., Korhonen, H., Ström, J., and Hansson, H.: Is nucleation capable of explaining observed aerosol integral number increase during southerly transport over Scandinavia?, Tellus B, 59, 129 $140,2006$.

Twomey, S.: Influence of Pollution on Shortwave Albedo of Clouds, J. Atmos. Sci., 34, 1149-1152, 1977.

VanReken, T., Ng, N., and Flagan, R.: Cloud condensation nucleus activation properties of biogenic secondary organic aerosol, J. Geophys. Res., 110, D07206, doi:10.1029/2004JD005465, 2005.

Vestin, A., Rissler, J., Swietlicki, E., and Frank, G.: Cloudnucleating properties of the Amazonian biomass burning aerosol: Cloud condensation nuclei measurements and modeling, J. Geo- 
phys. Res., 112, D14201, doi:10.1029/2006JD008104, 2007.

Wang, J., Lee, Y., Daum, P., Jayne, J., and Alexander, M.: Effects of aerosol organics on cloud condensation nucleus (CCN) concentration and first indirect aerosol effect, Atmos. Chem. Phys., 8, 6325-6339, doi:10.5194/acp-8-6325-2008, 2008.

Wex, H., McFiggans, G., and Henning, S.: Influence of the external mixing state of atmospheric aerosol on derived CCN number concentrations, Geophys. Res. Lett., 37, L10805, doi:10.1029/2010GL043337, 2010.

Whitehead, J. D., Gallagher, M. W., Dorsey, J. R., Robinson, N., Gabey, A. M., Coe, H., McFiggans, G., Flynn, M. J., Ryder, J., Nemitz, E., and Davies, F.: Aerosol fluxes and dynamics within and above a tropical rainforest in South-East Asia, Atmos. Chem. Phys., 10, 9369-9382, doi:10.5194/acp-10-9369-2010, 2010.
Wiedensohler, A.: An approximation of the bipolar charge distribution for particles in the submicron size range, J. Aerosol Sci., 19, 387-389, 1987.

Williams, P., McFiggans, G., and Gallagher, M.: Latitudinal aerosol size distribution variation in the Eastern Atlantic Ocean measured aboard the FS-Polarstern, Atmos. Chem. Phys., 7, 25632573, doi:10.5194/acp-7-2563-2007, 2007.

Zhou, J., Swietlicki, E., Hansson, H., and Artaxo, P.: Submicrometer aerosol particle size distribution and hygroscopic growth measured in the Amazon rain forest during the wet season, J. Geophys. Res, 107, 8055, doi:10.1029/2000JD000203, 2002. 